\section{Ankara Üniversitesi Eğitim Bilimleri Fakültesi Özel Eğitim Dergisi}

2021, 22(2), 369-394

\title{
Okul Psikolojik Danışmanı Adaylarının Özel Eğitim Öz-Yeterlik Algıları ve Yeterlilik Düzeyleri: Bir Karma Yöntem Çalışması
}

\author{
Öznur Bayar 1
}

\author{
Türkan Doğan 2
}

\begin{abstract}
$\ddot{O} z$
Giriş: Okul psikolojik danışmanları özel eğitim hizmetlerinde kritik bir role sahiptir ancak okul psikolojik danışmanı adaylarının öz-yeterlik algıları ve yeterlilikleri yeterince araştırılmamıştır.

Yöntem: Okul psikolojik danı̧̧manı adaylarının özel eğitimde öz-yeterlik algılarının ve yeterlilik düzeylerinin incelenmesinin amaçlandığı bu araştırmada yakınsak paralel karma desen (NIC+NIT) kullanılmıştır. Katılımcıların özel eğitim öz-yeterlik algılarını ölçmek için nicel ("Rehber Öğretmen Özel Eğitim Öz-Yeterlik Ölçeği"); özel eğitim yeterlilik düzeylerini ölçmek için nitel yöntem ("Vaka Sunumu ve Vaka ile İlgili Sorular Formu") kullanılmıştır. Katılımcılar Rehberlik ve Psikolojik Danışmanlık programı 3. ve 4. sınıf öğrencileridir ( $n$ $=233$ ).
\end{abstract}

Bulgular: Bulgulara göre katılımcıların özel eğitim öz-yeterlik algıları orta düzeydedir. Katılımcıların kimlik cinsiyeti ve sınıf düzeyine göre özel eğitim öz-yeterlikleri arasında anlamlı fark bulunmamıştır. Kaynaştırma dersi alanların özel eğitim öz-yeterlik puanları kaynaştırma dersi almayanlara göre yüksektir. Katılımcılar tanıdeğerlendirme için kurumlara başvuru, öğrenci için yapılacak eğitsel, kişisel/sosyal rehberlik, aileye ve öğretmenlere müşavirlik konularında bilgi sahibidir. Öte yandan katılımcılar yanıtlarında mesleki rehberlik ve hak savunuculuğu konularına daha az yer vermiştir.

Tartışma: Orta düzeydeki özel eğitim öz-yeterlik algısı bulgusu önceki araştırmalarla örtüşmektedir ve bu bulgu özel eğitimle ilgili sınırlı eğitim alınmasıyla ilgili olabilir. Okul psikolojik danışmanı adaylarının özel eğitimde mesleki rehberlik hizmetleri konusunda bilgilerini arttırmaları gerektiği gözlenmiştir. Aynı zamanda, okul psikolojik danışmanlığının önemli bir parçası olan hak savunuculuğuna dayalı ifadeler katılımcıların yanıtlarında fazla vurgulanmamıştır ve bu sebeple hak savunuculuğuna dayalı bilgi seviyesi arttırılmalıdır.

Anahtar sözcükler: Okul psikolojik danışmanı adayı, özel eğitim, özel eğitimde psikolojik danışma ve rehberlik, rehber öğretmen özel eğitim öz-yeterlik, özel eğitimde yeterlilik, vaka sunumu, karma yöntem.

Atıf için: Bayar, Ö., \& Doğan, T. (2021). Okul psikolojik danışmanı adaylarının özel eğitim öz-yeterlik algıları ve yeterlilik düzeyleri: Bir karma yöntem çalışması. Ankara Üniversitesi Eğitim Bilimleri Fakültesi Özel Eğitim Dergisi, 22(2), 369-394. https://doi.org/10.21565/ozelegitimdergisi.695682

\footnotetext{
${ }^{1}$ Sorumlu Yazar: Arş. Gör., Hacettepe Üniversitesi, E-posta: oznur.bayar@ hacettepe.edu.tr, https://orcid.org/0000-00029385-8641

2Prof. Dr., Hacettepe Üniversitesi, E-posta: dogant@hacettepe.edu.tr, https://orcid.org/0000-0002-5976-7666
} 


\section{Giriş}

Her çocuğun eğitim hakkı vardır. Özel eğitim ihtiyacı olan her çocuğun da özel gereksinim türü ve derecesine bakılmaksızın, eğitimden yararlanma hakkı vardır. Eğitimde firsat eşitliğinin sağlanması için her çocuğa eğitim hakkı verilmesi gerekmektedir ve firsat eşitliği her çocuğa kapasitesine uygun eğitimin verilmesini de gerektirir. Dolayısıyla özel eğitim, genel eğitimin ayrılmaz bir parçasıdır. Bu kapsamda Türkiye'de özel eğitim hizmetlerinin amacı "özel gereksinimli bireylerin eğitim ihtiyaçları, yeterlilikleri, ilgi ve yetenekleri doğrultusunda kapasitelerini en üst düzeyde kullanmaları, üst öğrenime, meslek hayatına ve toplumsal yaşama hazırlanmaları'dır (Millî Eğitim Bakanlığı [MEB], 2018). Söz konusu amaca ulaşmak için çeşitli kurum ve kuruluşların iş birliği içinde çalışması gerekmektedir.

Rehberlik Araştırma Merkezleri (RAM) özel eğitim hizmetlerinin en önemli öğelerinden biri olarak görülmektedir ve Millı̂ Eğitim Bakanlığına bağlı kurumlardan yönlendirilen öğrencilerin eğitsel tanılama ve değerlendirme süreçleri RAM'da yürütülmektedir (MEB, 2017, 2020a). Öte yandan, özel gereksinimli öğrencilerle ilgili değerlendirme sürecinin ilk basamağı genellikle okullarda hatta sınıflarda başlamaktadır. Sınıflarda özel gereksinimi olabilecek öğrencileri belirlemek ve öğrencilerin sınıf içi ihtiyaçlarını karşılamak ön koşuldur ve öğrenciyi RAM'a yönlendirme aşamasına kadar geçen süreçte sınıf öğretmeni ile okul psikolojik danışma ve rehberlik servisinin birlikte çalışması gerekmektedir (Kargın, 2007). Dolayısıyla eğitim kurumlarında özel gereksinimli çocuklara ulaşmada ve onların özel eğitim gereksinimine uygun eğitim ve hizmetlerin verilmesinde MEB'e bağlı okul ve kurumlarda çalı̧̧an okul psikolojik danışmanları kritik bir öneme sahiptir.

Okul psikolojik danışmanlarının görevlerine dair düzenlemeler içeren ve 2017 yılından itibaren geçerli olan Millî Eğitim Bakanlığı Rehberlik Hizmetleri Yönetmeliğinde özel eğitimle ilgili görevler; eğitsel değerlendirme ve tanılama ekibine katılma, bireyselleștirilmiş eğitim programı (BEP) geliştirme ekibinde rehberlik hizmetlerini yürütmek için yer alma, özel gereksinimli öğrenci ve ailelerin ihtiyacı olabilecek kişi, kurum ve kuruluşlarla iş birliği yapma, destek eğitim odasında öğrencilerin gelişimi takip etme şeklinde sıralanmaktaydı (MEB, 2017). Güncellenen ve Ağustos 2020 'den itibaren yürürlüğe konan Rehberlik ve Psikolojik Danışma Hizmetleri Yönetmeliğinde ise (MEB, 2020b), okul psikolojik danışmanının özel eğitim hizmetleriyle ilgili yukarıda sıralanan maddeler yönetmelikten çıkarılmıştır ancak bu hizmetler Özel Eğitim Hizmetleri Yönergesinde (MEB, 2020a) yer almıştır. Öte yandan, söz konusu yönetmelikte okul psikolojik danışmanlarının özel eğitimle ilgili görevlerine dair bir netlik olduğunu söylemek güçtür. Örneğin, okullarda kurulan BEP geliştirme ekibinde rehber öğretmen/psikolojik danışman bir üye olarak yer almaktadır ancak ekipteki iş bölümünde nasıl bir rolü olduğu netleştirilmemiştir.

Aynı zamanda, yine 2020 yılında yürürlüğe giren Rehberlik ve Psikolojik Danışma Hizmetleri Etik Yönergesinde (MEB, 2020c), rehberlik ve psikolojik danışma hizmetlerinin tüm öğrencileri kapsaması için önlemler alınması, öğrencilerin özel eğitim ihtiyacı gibi bireysel farklılıklarına ve gelişimsel özelliklerine uygun psikolojik ölçme araçlarının kullanılması ve psikolojik danışma ve rehberlik alanının mesleki yeterliklerinin dışında kalan alanlarda yardıma ihtiyacı olan öğrencilerin uzmanlara sevk edilmesi gibi usül ve esaslar tanımlanmıştır. Açıklanan bu görevler, okul psikolojik danışma ve rehberlik servisinin verdiği tüm hizmetlerin özel gereksinimli öğrencileri de kapsadığını ve özel gereksinimli öğrencilerle ilgili hizmet veren diğer kurumlarla işbirliği içinde çalışılması gerektiğini göstermektedir. Özel gereksinimli öğrencilere yönelik rehberlik çalışmaları, tıpkı tüm öğrencilere yönelik hizmetlerde olduğu gibi, problem alanlarına göre eğitsel, kişisel-sosyal ve mesleki rehberlik olarak sınıflandırılabilir. Okul psikolojik danışmanları özel gereksinimli öğrencilere, öğrencilerin ailelerine ve öğretmenlerine yönelik çalışmalarda da aktif bir görev almaktadır. Ailelere ve öğretmenlere yönelik bu rehberlik hizmetleri ise müşavirlik/konsültasyon kapsamında değerlendirilebilir (Yeşilyaprak, 2016). Alanyazında özel gereksinimli olan çocukların ihtiyacı olan hizmetleri alabilmesi için okul psikolojik danışmanlarının aileyi bilgilendirmesi ve yönlendirmesinin önemli olduğunun da altı çizilmektedir (Cimsir \& Hunt, 2018). Fairchild (1985), özel gereksinimli öğrencilerin gelişimi için çok disiplinli bir takım çalışması gerektiğini vurgulamakta ve bu ekibin çoğunlukla öğrencilerin akademik ihtiyaçlarına odaklandığını belirtmekte; ögrencilerin akademik olmayan ihtiyaçlarını gündeme getirmede ise okul psikolojik danışmanının kritik bir rolü olduğunu vurgulamaktadır.

Özel gereksinimli öğrencilerin akademik olmayan ihtiyaçlarının gündeme getirilmesi konusu akla hak savunuculuğu kavramını (advocacy) getirmektedir. Diğer bir deyişle okul psikolojik danışmanlarının özel gereksinimli öğrencilerle ilgili üstlenebileceği bir sorumluluk da hak savunuculuğu kapsamında değerlendirilebilir (Geltner \& Leibforth, 2008). Özel gereksinimli öğrenciler için yasal düzenlemeler yapılmış olmasına rağmen uygulamada öğrencilerin haklarının gözetilmesi için savunuculuk ihtiyacı doğabilir ve okul psikolojik danışmanı 
bu noktada öğrencilerin ailelerini, öğretmenlerini ve okuldaki diğer personelleri bilgilendirecek mercii haline gelebilir (Cimsir \& Hunt, 2018). Hatta okul psikolojik danışmanlarının, özel gereksinimli öğrencilerin haklarını koruma konusunda sorumluluk alabilecek en kritik konumdaki kişi olduğu vurgulanmaktadır (Owens vd., 2011). Güncel bir gelişme olarak, Rehberlik ve Psikolojik Danışma Hizmetleri Etik Yönergesinde, duyarlılık ilkesi kapsamında okul psikolojik danışmanı tarafından özel gereksinimli öğrencilerin güçledirilmesi ve eğitimden en üst düzeyde yararlanmasına engel olan durumların ortadan kaldırılması için gayret gösterilmesi gerektiği açıklanmıştır (MEB, 2020c). Tanımlanan bu görevin, okul psikolojik danışmanlarının hak savunuculuğu rolüne işaret ettiği düşünülebilir.

Türkiye'de 1983’te 2916 Sayılı Özel Eğitime Muhtaç Çocuklar Hakkında Kanunun çıkmasıyla birlikte kaynaştırma uygulamaları sistemi oluşturulmaya başlanmıştır (Sucuoğlu, 2004). Ardından 1997 yılında çıkarılan 573 sayılı Özel Eğitim Hakkında Kanun Hükmünde Kararname ile özel gereksinimli öğrencilerin genel ve mesleki eğitim süreçlerinde izlenecek ilkeler, tanılama, yerleştirme ve eğitim süreçleri, özel eğitimin temel ilkeleri konularının esasları belirlenmiştir (MEB, 2010). Bu kanuna dayalı çıkarılan ve 2000 yılında yürürlüğe giren "Özel Eğitim Hizmetleri Yönetmeliği” ile kaynaştırma hizmetlerinin ilkeleri açıklanmıştır (Sucuoğlu, 2004). Söz konusu yönetmelik 2018 yılında güncellenmiştir ve aynı zamanda 2020 yılında yönetmelikte çeşitli değişiklikler yapılmıştır. Söz konusu yönetmelikte özel gereksinimli bireylerin alacağı eğitim hizmetleri ayrıntılı şekilde ele alınmıştır (MEB, 2018, 2020a). Türkiye' de kaynaştırma yoluyla eğitim alan özel gereksinimli öğrenci sayısı 2018 - 2019 eğitim öğretim yılında ilkokul düzeyinde 115.556, ortaokul düzeyinde 130.624 ve ortaöğretim düzeyinde ise 48.257 olarak belirtilmektedir (MEB, 2019). Dolayısıyla her okul psikolojik danışmanının özel gereksinimli öğrencilere, bu öğrencilerin öğretmenlerine ve ebeveynlerine hizmet verme olasılığ son derece yüksektir. Tüm bunlardan hareketle okul psikolojik danışmanlarının özel eğitim konusunda bilgili ve yeterli olmalarının kurumsal bir beklenti ve rehberlik hizmetlerinin temel ilkesi gereği tüm öğrencilere sunulması gereken bir hizmet olmasından ötürü (Yeşilyaprak, 2016) etik bir sorumluluk olduğu söylenebilir.

Okul psikolojik danışmanlarının özel eğitim öz-yeterlik algı düzeylerinin, özel eğitime ilişkin verdikleri hizmetleri etkilediği söylenebilir. Öz-yeterlik bireyin bir işi başarılı şekilde gerçekleştirmesi ile ilgili kendi kapasitesine yönelik inancı olarak özetlenebilir (Bandura, 1982). Öz-yeterlik "genel öz-yeterlik" olarak incelenebileceği gibi farklı alanlara ilişkin de tanımlanabilmektedir ve bunlardan biri de mesleki öz-yeterliktir. Okul psikolojik danışmanı adaylarıyla yapılan çalışmalar; yeterli olmaya ilişkin kişisel inancın okul psikolojik danışmanlarının performansını ve başarısını etkilediğini göstermektedir (Bodenhorn \& Skaggs, 2005). Benzer şekilde okul psikolojik danışmanlarının özel eğitime yönelik uygulamalarına ilişkin öz-yeterlik algıları da performanslarıyla ilişkili görülmektedir (Aksoy \& Diken, 2009a). Alanyazında meslekte deneyimli olan okul psikolojik danışmanlarının öz-yeterlik düzeylerinin deneyimi daha az olanlardan daha yüksek olduğu bulgulanmıştır (Aksoy \& Diken, 2009b). Dolayısıyla bilgi ve deneyimin öz-yeterlik algısını etkilediği söylenebilir. Türkiye'de okul psikolojik danışmanlarının özel eğitim öz-yeterlik algısı ile mesleki tükenmişliklerinin negatif yönde ilişkili olduğu ortaya konmuştur (Kumcağız vd., 2017). Tüm bunlar göstermektedir ki özel eğitim konusundaki bilgi eksiklerinin mezun olmadan giderilmesi hem okul psikolojik danışmanlarının kendilerini daha yeterli hissetmelerini sağlaması ve mesleki tükenmişliğin önlenmesi açısından hem de hizmet sunacakları öğrencilerin ihtiyacı olan hizmetleri etkili ve hızlı biçimde alabilmesi açısından önemlidir. Buradan hareketle okul psikolojik danışman adaylarının özel eğitime ilişkin yeterlilikleri ve bu konudaki öz-yeterlik algılarına odaklanılması önemli görülmektedir.

Uluslararası alanyazında, okul psikolojik danışmanlarının özel eğitimdeki rolü her ne kadar kıymetli görülse de bu konuda mezuniyet öncesi veya sonrası eğitim alma oranlarının düşük olduğu ifade edilmektedir (Dunn \& Baker, 2002). Türkiye' de de durumun benzer olduğu söylenebilir. Rehberlik ve Psikolojik Danışmanlık (RPD) lisans programları incelendiğinde 2018 yılına dek zorunlu statüde kuramsal bir ders olarak "Özel Eğitim" dersinin verildiği ve bazı programlarda buna ek olarak seçmeli statüde "Kaynaştırma Uygulamaları” dersinin açıldığı görülmektedir (Örneğin, Ankara Üniversitesi Lisans Programı, 2019). Türkiye’de RPD lisans programı 2018 yılından itibaren tüm üniversitelerde standartlaştırılmıştır (Yükseköğretim Kurulu [YÖK], 2018) ve ilgili programda yine özel eğitim konusunda "Özel Eğitim ve Kaynaştırma" adıyla sadece bir zorunlu derse yer verilmiştir. Bunun yanında meslek bilgisi ve alan eğitimi seçmeli dersleri kapsamında "Dikkat Eksikliği ve Hiperaktivite Bozukluğu, Özel Yetenekli Çocuklar ve Eğitimi ve Dezavantajlı Gruplarla Kariyer Danışmanlığı” gibi derslerin eklenmesi özel eğitim konusunda yeterlilik düzeyinin arttırılabilmesi yönünde umut vericidir. Öte yandan bu araştırmanın çalışma grubunu 2018 öncesinde eğitim hayatına başlayan ve yeni programa tabii olmayan lisans öğrencileri oluşturmaktadır. Dolayısıyla katılımcıların "Özel Eğitim” veya "Kaynaştırma” dışında ders almış olmaları olası görünmemektedir. Araştırma kapsamında seçmeli statüsünden dolayı "Kaynaştırma” dersini 
de almayan öğrencilere rastlanması olası bulunmuştur. Bu çerçevede bu çalışmada özel eğitim ile ilgili ders alan ve almayan öğrencilerin özel eğitim öz-yeterlik algılarının farklı olup olmadığının incelenmesi de amaçlanmıştır.

Türkiye'de ilgili alanyazın incelendiğinde okul psikolojik danışman adaylarının özel eğitim öz-yeterlik algılarının orta düzeyde (Deniz, 2016; Sönmez vd., 2020) ve orta düzeyin biraz altında bulunduğu (Yüksel vd., 2012) görülmektedir. Okul psikolojik danışmanı olarak görev yapanların özel eğitim öz-yeterlik düzeyleri incelendiğinde ise yine öz-yeterlik algılarının orta düzeyde olduğu görülmektedir (Aksoy \& Diken, 2009b). Ancak sözü edilen çalışmalarda katılımcıların öz-yeterlik algılarının nicel yolla ölçülmesiyle sınırlı kalınmıştır ve de katılımcıların özel eğitim konusunda ne gibi hizmetler sunabileceklerinin üzerinde durulmamıştır. Her ne kadar MEB tarafından yayınlanan yönetmeliklerde özel eğitimle ilgili çeşitli maddeler yer alsa da Türkiye'de okul psikolojik danışmanlarının özel gereksinimi bulunan öğrencilere verecekleri hizmetlerde yönetmelikler bakımından netlik olduğunu söylemek güçtür (Cimsir \& Hunt, 2018; Sütçü, 2007). Bu bakımdan okul psikolojik danışmanı adaylarının özel gereksinimli öğrencilerle ilgili verecekleri her türlü rehberlik hizmetine dair mesleki bir temel oluşturmuş olarak görevlerine başlamaları gerekmektedir. Buradan hareketle bu araştırmada katılımcıların özel eğitim öz-yeterlikleriyle ilgili algılarını ölçmenin yanı sıra, okul psikolojik danışmanı olarak özel gereksinimi olabilecek bir öğrenciyle karşılaşıldığında tanı ve değerlendirme için yönlendirme, öğrencinin gelişimi için eğitsel, kişisel/sosyal ve mesleki rehberlik çalışmaları, özel gereksinimli çocuğun ailesi ve öğretmenlerine yönelik müşavirlik hizmeti kapsamında neler yapabileceklerine dair yeterlilik düzeylerinin nitel yolla ölçülmesi amaçlanmıştır. Özetle bu araştırmanın amacı okul psikolojik danışmanı adaylarının özel eğitim öz-yeterlik algılarının ve yeterlilik düzeylerinin belirlenmesidir. Bu çerçevede araştırmanın alt problemleri şu şekildedir:

1. Okul psikolojik danışmanı adaylarının özel eğitim öz-yeterlik algı düzeyleri nasıldır?

2. Okul psikolojik danışman adaylarının özel eğitim öz-yeterlik algıları kimlik cinsiyetlerine, sınıf düzeylerine ve özel eğitim ile ilgili ders alıp almamalarına göre fark göstermekte midir?

3. Okul psikolojik danışman adaylarının özel gereksinimli öğrencilere yönelik yapılacak rehberlik çalışmalarıyla ilgili (eğitsel, mesleki, kişisel/sosyal) yeterlilik düzeyleri nedir?

4. Okul psikolojik danı̧̧man adaylarının özel gereksinimli öğrencilerin ailelerine yönelik yapılacak rehberlik çalışmalarıyla ilgili yeterlilik düzeyleri nedir?

5. Okul psikolojik danışman adaylarının özel gereksinimli öğrencilerin öğretmenlerine yönelik yapılacak rehberlik çalışmalarıyla ilgili yeterlilik düzeyleri nedir?

\section{Yöntem}

\section{Araştırma Deseni}

$\mathrm{Bu}$ araştırmada nitel ve nicel verilerin birlikte toplandığı karma yöntem desenlerinden yakınsak paralel karma desen (convergent parallel mixed design) kullanılmıştır. Karma desenler eğitim bilimleri ve sosyal bilim araştırmalarında derinlemesine bilgiye ihtiyaç duyulduğunda, nicel ve nitel verilerin birlikte kullanılması amacıyla tercih edilebilmektedir (Creswell vd., 2003). Okul psikolojik danışmanı adaylarının özel eğitim öz-yeterlikleri ve bununla bağlantılı bir kavram olan özel eğitim yeterlilikleri sınırlı sayıda araştırmaya konu edildiğinden, konunun derinlemesine incelenmesine ihtiyaç duyulmuştur. Araştırmanın nicel boyutunda ölçek; nitel boyutunda ise vaka çalışması (durum çalışması) yöntemi kullanılmıştır.

Creswell'e göre (2014) karma araştırma desenlerinde nicel ve nitel verilerin toplanma zamanlaması aynı anda (concurrently) veya sıralı (sequential) olabilmektedir. Bu çalışmada elde edilen nicel ve nitel veriler aynı anda toplanmıştır ve tek aşamada tamamlanmıştır. $\mathrm{Bu}$ araştırmada elde edilen nicel ve nitel verilere önem bakımından eşit ağırlık (weightining) verilmiştir (Creswell vd., 2003). Bir başka deyişle bu araştırmada, nicel ve nitel bulgulara eşit düzeyde vurgu yapılması amaçlanmıştır. Yakınsak paralel karma araştırma deseninde nicel ve nitel veriler eş zamanlı toplanır, analizler ayrı ayrı yapılır ve bulgular bütünleştirilerek yorumlanır (Creswell, 2014). Bu çalışmada katılımcıların özel eğitim öz-yeterlik algıları yeterlilik düzeyleriyle ilgili nicel ve nitel veriler birlikte toplanmış, bağımsız olarak analiz edilmiş ve bulgular tartışma aşamasında bütünleştirilmiştir. Tüm bunlardan hareketle bu araştırmanın deseni NİC+NITT olarak formülize edilebilir.

\section{Çalışma Grubu}

Çalışma grubunu Ankara'da dört farklı üniversitede okuyan Rehberlik ve Psikolojik Danışmanlık (RPD) lisans programı öğrencileri oluşturmaktadır $(n=233)$. Öğrenciler üçüncü sınıf $(n=118 ; \% 50.64)$ ve dördüncü 
sınıf ( $n=112 ; \% 48.06)$ düzeyindedir. Üç katılımcı (\%1.3) ise sınıf düzeyini belirtmemiştir. Katılımcıların 186'sı (\%79.8) kadın, 47'si (\%20.2) erkektir. Yaşlarını belirten katılımcıların yaşları 19 ile 37 arasında değişmektedir ( $n$ $=213, \bar{X}=21.63, s s=1.89)$. Katılımcıların 229'u (\%98.3) “Özel eğitim” dersi aldığını; 4'ü ise (\%1.7) almadığını belirtmiştir. Katılımcıların 74’ü (\%31.8) "Kaynaştırma” dersi aldığını; 159'u ise (\%68.2) almadığını belirtmiştir.

Çalışma grubuna nicel verilerle eş zamanlı olarak vaka sunumu ve vaka ile ilgili sorular formu sunulmuştur. Katılımcıların $185^{\prime}$ i (\%79.4) nitel formda en az bir soruya yanıt yazmıştır. Katılımcıların 39'u (\%16.7) sorularla ilgili “Fikrim yok" seçeneğini işaretlemiş; 9'u ise (\%3.9) herhangi bir işaretleme yapmaksızın soruların tamamını boş bırakmıştır. Dolayısıyla nitel analizlerde 185 katılımcının yanıtı değerlendirilmiştir. En az bir soruya yanıt veren katılımcıların "Fikrim yok" seçeneğini işaretleme durumları her bir soru için ayrı ayrı sayılarak bulgularda sunulmuştur.

\section{Veri Toplama Araçları \\ Rehber Öğretmen Özel Ĕ̆itim Öz Yeterlik Ölçeği}

Bu çalışmada Aksoy ve Diken (2009a) tarafından geliştirilen Rehber Öğretmen Özel Eğitim Öz Yeterlik Ölçeği (RÖ-ÖEÖYÖ) kullanılmıştır. Söz konusu ölçeğin geçerlik ve güvenirlik çalışmaları rehber öğretmenlerden toplanan verilerle gerçekleştirilmiştir. Ölçeğin geçerlik çalışmaları kapsamında uzman görüşü yoluyla kapsam geçerliği; Açıklayıcı Faktör Analizi (AFA) yoluyla yapı-kavram geçerliği sağlanmıştır. Sonuçlara göre ölçek tek faktörlü 40 maddeden oluşan beşli likert tipi derecelendirmeli $(1=$ Tamamen katılmıyorum, $5=$ Tamamen katılıyorum) bir kendini anlatma ölçeğidir. Yapılan madde analizi ile ölçeğin alt ve üst \%27'lik grupları ayırt edebildiği sonucuna ulaşılmıştır ve madde-toplam korelasyon katsayılarının .49 ile .84 arasında kabul edilir sınırlarda olduğu görülmüştür. Test - tekrar test korelasyon katsayısı $(r=.96)$ ve Cronbach Alfa iç tutarlık katsayısı $(r=.98)$ sonuçları ölçeğin kararlılık ve tutarlık bakımından güvenilir olduğunu ortaya koymuştur (Aksoy \& Diken, 2009a).

$\mathrm{Bu}$ çalışmada ise, ölçek geliştirilirken geçerlik güvenirlik çalışması yapılan gruptan farklı bir çalışma grubu olan okul psikolojik danışmanı adayları ile çalışmıştır. RÖ-ÖEÖYÖ’nün RPD bölümüne devam eden öğrencilere yönelik geçerlik güvenirlik çalışmaları daha önceki bir çalışmada gerçekleştirilmiştir (Yüksel vd., 2012). Ölçeğin RPD öğrencileri için geçerlik çalışmaları kapsamında yapı-kavram geçerliği için AFA, maddelerin ayırt edicilik gücü için madde analizi yapılmıştır. Elde edilen sonuçlar ölçeğin tek boyutunun korunduğunu, her maddenin faktör yük değerlerinin kabul edilir aralıkta olduğunu (.46-.81), ölçeğin alt ve üst \%27'lik grupları ayırt etme gücü olduğunu ve madde toplam korelasyonlarının .44 ile .79 arasında değiştiğini göstermiştir. Ölçeğin güvenirliği için hesaplanan test - tekrar test korelasyon katsayısı .98 $(p<.05)$ ve Cronbach alfa iç tutarlık katsayısı $.97(p<.05)$ bulunmuştur. Buradan hareketle ölçeğin RPD öğrencilerinde geçerli ve güvenilir olarak kullanılabileceği ortaya konmuştur. Ölçeğin okul psikolojik danışmanı adaylarıyla yapılan farklı çalışmalarda da güvenilir şekilde kullanıldığı ve geçerli sonuçlar verdiği görülmüştür (Deniz, 2016). Dolayısıyla ölçeğin bu çalışmada da kullanılabileceğine karar verilmiştir. Bu çalışmada elde edilen veri setinde RÖ-ÖEÖYÖ’nün tüm maddeleri için Cronbach alfa iç tutarlık katsayısı .96 olarak hesaplanmıştır.

\section{Vaka Sunumu ve Vaka ile İlgili Sorular Formu}

Nitel veriler için katılımcılara okul psikolojik danışmanı olarak çalışırken karşılaşabilecekleri özel eğitimle ilişkili bir örnek vaka sunulmuştur. Vaka, araştırmacılar tarafından oluşturulmuştur. Vaka ve vaka ile ilgili sorular hakkında özel eğitim ve psikolojik danışma ve rehberlik alanında çalışan iki uzmandan görüş alınmıştır. Uzmanlar vakayı ve soruları uzunluğu, açıklığı, amaca hizmet etmesi ve etik olarak sakıncalı olup olmaması bakımından değerlendirmiştir. Uzmanların görüşleri doğrultusunda vakada ve vakaya ilişkin sorularda küçük değişiklikler yapılmıştır. Uzmanlar katılımcıların gönüllülüklerini olumsuz etkilememesi için tek vakanın sunulmasını uygun bulduklarını eklemiştir. Vakada okul psikolojik danışma servisine sınıf öğretmeni tarafından yönlendirilmiş; akıcı konuşma konusunda güçlük çeken ve bununla ilgili kaygı yaşayan; İngilizce ve Türkçe derslerinde zorlanan, arkadaş ve öğretmenleriyle sınırlı seviyede iletişim kuran ilkokul 4. sınıf düzeyinde bir öğrenciden söz edilmektedir. Katılımcılara söz konusu vakayla ilgili (1) Öğrencinizin dil ve konuşma bozukluğu olup olmadığının belirlenmesi amacıyla hangi kuruma/kurumlara başvururdunuz? Başvuruda nasıl bir yol izlerdiniz? (2) Bu öğrenciye nasıl bir destek sunardınız? Eğitsel, mesleki ve kişisel/sosyal rehberlik kapsamında ne tür çalışmalar yapardınız? (3) Öğrencinizin ailesine nasıl bir destek sunardınız? Bu konuda ne tür çalışmalar yapardınız? (4) Öğrencinizin sınıf öğretmenine nasıl bir destek sunardınız? Bu konuda ne tür çalışmalar yapardınız? soruları yöneltilmiştir. Katılımcılardan eğer bu soruların yanıtlarıyla ilgili hiçbir fikirleri yoksa her bir soru için "Fikrim yok" seçeneğini işaretlemeleri istenmiştir. 


\section{Kişisel Bilgi Formu}

Bu form katılımcıların kimlik cinsiyeti, yaşı, okulu, sınıf düzeyi ve özel eğitim ve kaynaştırma dersi alıp almadıkları ile ilgili bilgileri barındırmaktadır.

\section{Veri Toplama ve Analizi}

$\mathrm{Bu}$ çalışmada kullanılan veriler 2017-2018 eğitim öğretim yılında bu araştırmaya gönüllü olarak katılmayı kabul eden öğrencilerden toplanmıştır. Uygulamalar sınıf ortamında uygun ders saatlerinde gerçekleştirilmiştir. Uygulamacılar Psikolojik Danışma ve Rehberlik alanında en az yüksek lisans düzeyinde eğitimini tamamlamış; nitel ve nicel araştırmalar konusunda alan deneyimi olan akademisyenlerdir. Belirlenen gün ve saatte gidilen sınıflarda katılımcılara araştırmaya gönüllü olarak katılıp katılmadıkları sorulmuştur ve gönüllülerden veri toplanmıştır. Araştırmaya katılmayı kabul eden katılımcılara Bilgilendirilmiş Onam ve Gönüllü Katılım Formu imzalatılmıştır. Bu formda araştırmaya ve araştırmacılara ilişkin bilgiler ve katılımcının sahip olduğu haklara yer verilmiştir. Kişisel bilgi formu ile nitel ve nicel veri toplama araçlarının yer aldığı uygulama formlarında ise imza, kimlik bilgileri ve iletişim bilgileri yer almamıştır ve öğrencilere bu bilgilerini forma yazmamaları hatırlatılmıştır. Dileyen katılımcıların sonuçlarla ilgili bilgilendirilebilmesi için araştırmacıların eposta adresi uygulama esnasında paylaşılmıştır. Katılımcılara veri setini doldurmayı istedikleri anda bırakıp araştırmadan ayrılma konusunda özgür oldukları, yarım bırakmanın kendilerine hiçbir yükümlülük getirmeyeceği ve araştırmadan ayrılmaya karar vermeleri halinde kendilerinden edinilen hiçbir bulgunun değerlendirmeye alınmayacağı sözel olarak da hatırlatılmıştır. Katılımcıların formlara tepki vermesi 10-15 dakika arası sürmüştür.

\section{Nicel Verilerin Analizi}

Katılımcıların özel eğitim öz-yeterlik düzeyleri RÖ-ÖEÖYÖ’den alınan puanlar üzerinde betimsel istatistiklerin hesaplanmasıyla elde edilmiştir. Özel eğitim puanlarının düzeyinin belirlenmesi için katılımcılardan elde edilen veriler kullanılarak z puanı hesaplanmış ve bağıl değerlendirme ile kesme puanları oluşturulmuştur. $\mathrm{Bu}$ araştırmada katılımcıların neredeyse tamamının özel eğitim dersi alması sebebiyle özel eğitim dersi alanlar ve almayanlar arasında özel eğitim öz-yeterlik puan ortalamaları bakımından fark olup olmadığ test edilememiştir. Öte yandan katılımcıların kaynaştırma dersi alıp almama durumlarına, kimlik cinsiyetlerine ve sınıf düzeylerine göre gözlenen öz-yeterlik düzeyleri puan ortalamaları arasında fark olup olmadığı incelenmiştir. Analiz için öncelikle veri setinin dağılımı incelenmiştir. Normallik testi için Kolmogorov-Smirnov (K-S) testi yapılmıştır ve değerler dağılımın normal dağılımdan anlamlı derecede sapmadığını göstermiştir $(p>.05)$. Varyansların homojenliği için ise Levene $F$ testi kullanılmıştır ve varyanslar homojen bulunmuştur $(p>.05)$. Buradan hareketle, her grubun test puanlarının normal dağıldığı ve gruplar arası puan ortalamalarının karşılaştırılmasında parametrik bir test olan bağımsız örneklemler t testinin kullanılmasının uygun olduğuna karar verilmiştir. Nicel verilerin analizinde SPSS 23.0 paket programı kullanılmıştır.

\section{Nitel Verilerin Analizi}

Nitel verilerin analizinde betimsel analiz kullanılmıştır. Betimsel analizde amaç, nitel bulguların özetlenerek anlaşılır biçimde sunulmasıdır (Yıldırım \& Şimşek, 2003). Araştırmada katılımcılara yöneltilen her soru ayrı ayrı analiz edilmiştir. İlk adımda katılımcıların her birine bir kod verilmiştir ve el yazısı ile elde edilen veriler analize hazırlanmak için Microsoft Office Word programına aktarılmıştır. Her soru için tüm katılımcıların verdiği yanıtlar okunarak veri seti tanınmıştır. Daha sonra verilen yanıtlarla ilgili betimleyici kodlar yazılmıştır ki bu kodlar verilerin kümelenmesine hizmet etmektedir. Daha sonra veri setinde ilk düzey kodlar anlamlı yapılar olarak bir araya getirilmiş ve örüntü kodları ortaya çıkmıştır. Örüntü kodları Microsoft Office Excel programına aktarılmış ve ilgili ifadeler kodlara uygun şekilde işlenmiş ve ardından örüntü kodlarında yer alan ifadeler sayılarak frekansları belirlenmiştir. Son adımda ise nitel veriler yorumlanarak bulgular haline getirilmiştir (Creswell, 2014). Nitel verilerin sunulmasında katılımcıların ifadelerinin örneklendirilmesi yolu tercih edilmiştir. Bu amaçla analiz aşamasında, katılımcıların sunuma uygun olan ifadeleri katılımcı kodlarıyla birlikte kaydedilmiştir. Daha sonra bu ifadeler, kategori ve alt kategorilerin belirlenen temaları yansıttığına kanıt olarak araştırma bulgularına eklenmiştir.

Nitel verilerin geçerliğini arttırmak için analiz aşamasında eş denetleme/uzman incelemesi (peer debriefing) kullanılmıştır (Creswell, 2014). Özel eğitim alanında uzmanlık derecesi olan bir araştırmacıdan nitel analizi incelemesi ve sorular sorması istenmiştir. Uzmanın kategorilerin adlandırılması, çeşitli kavram ve terimlerin kullanımı ve analiz birimlerinin kavramı yansıtacak şekilde düzenlenmesi ile ilgili önerileri de dikkate alınmıştır. Nitel araştırmanın güvenirliğini arttırmak için ise Gibbs (2007) (akt., Creswell, 2014) tarafından önerildiği üzere veri girişlerinde hata olup olmadığı kontrol edilmiş ve kodlamalarda anlam kaybı olup olmadığ1 
analizin her aşamasında gözden geçirilmiştir. Ayrıca bağımsız kodlama yapan araştırmacılar güvenirliği arttırmak için temalar ve kategorilerle ilgili fikir birliğine varana dek bir araya gelerek çalışmıştır. Kodlayıcılar arası görüş birliği $\Delta=\mathrm{C} \div(\mathrm{C}+\partial) \times 100$ formülü kullanılarak hesaplanmıştır. Formülde $\mathrm{C}$ : Görüş birliği sağlanan konu, $\partial$ : Görüş birliği sağlanmayan konu sayısını ifade etmektedir. Miles ve Huberman'a göre (1994) (akt., Baltacı, 1997) kodlayıcılar arasındaki görüş birliğinin en az $\% 80$ olması beklenmektedir Bu araştırmada söz konusu görüş birliği oranı \% 87 bulunmuştur ve buradan hareketle gerçekleştirilen nitel analizin güvenilirliğinin sağlandığı söylenebilir.

\section{Bulgular}

\section{Nicel Bulgular}

Araştırmanın amacına uygun olarak bu bölümde ilk olarak katılımcıların özel eğitim öz-yeterlik alg1 düzeyleri incelenmiş̧tir. Tablo 1'de katılımcıların özel eğitim öz-yeterliği puanları ve bu puanların düzeylerine ilişkin betimsel istatistikler sunulmuştur.

Tablo 1

Katılımcıların Özel Eğitim Öz-Yeterliği Puanları Betimsel Istatistikleri

\begin{tabular}{ccccccc}
\hline Ölçek & Puan aralığ1 & Düzey & $f$ & $\%$ & $\bar{X}$ & ss \\
\hline \multirow{2}{*}{ RÖ-ÖEÖYÖa $^{a}$} & $64-101$ & Alt & 23 & 9.9 & & \\
& $102-162$ & Orta & 196 & 84.1 & 132.13 & 22.70 \\
& $163-200$ & Üst & 14 & 6.0 & & \\
\hline
\end{tabular}

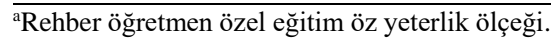

Katılımcıların özel eğitim öz-yeterlik puanları 64 ile 200 arasında değişmektedir ve puan ortalaması $132.13(n=233 ; s s=22.70)$ olarak bulunmuştur. Katılımcıların puan ortalamaları dikkate alınarak hesaplanan z puanları ile alt (64-101), orta (102-162) ve üst (163-200) gruplar belirlenmiştir. Bu değerlendirmeye göre katılımcıların puan ortalamaları 132.13 ile orta düzeydedir.

Çalışmada ikinci olarak katılımcıların özel eğitim öz-yeterlik puanlarıyla sahip oldukları bazı değişkenler arasında istatistiksel fark olup olmadığı incelenmiştir. Bu kapsamda Tablo 2'de katılımcıların özel eğitim özyeterlik algılarına ilişkin gözlenen puan ortalamaları ile kimlik cinsiyetleri arasında fark olup olmadığına ilişkin bulgu sunulmuştur. Ayrıca katılımcıların özel eğitim öz-yeterlik algıları puan ortalamaları ile kaynaştırma dersi alıp almamalarına ve sınıf düzeylerine göre fark olup olmadığına ilişkin yapılan bağımsız gruplar $t$ testi sonuçları sunulmuştur.

\section{Tablo 2}

Katılımcıların Kimlik Cinsiyeti, Kaynaştırma Dersi Alıp Almamaları ve Sinıf Düzeyine Yönelik Bağımsız Gruplar T-Testi Sonuçları

\begin{tabular}{cllcccccc}
\hline Ölçek & \multicolumn{1}{c}{ Değişkenler } & \multicolumn{1}{c}{ Gruplar } & $n$ & $\bar{X}$ & ss & $s d$ & $t$ & $p$ \\
\hline & \multirow{2}{*}{ Kimlik Cinsiyeti } & Kadın & 186 & 131.77 & 22.63 & \multirow{2}{*}{231} & -.481 & .631 \\
& & Erkek & 47 & 133.56 & 23.18 & & & \\
\multirow{2}{*}{ RÖ-ÖEÖYÖa $^{a}$} & Kaynaştırma dersi & Ders aldı & 74 & 138.98 & 23.60 & \multirow{2}{*}{231} & 3.207 & $.002^{*}$ \\
& & Ders almadı & 159 & 128.94 & 21.61 & & & \\
& \multirow{2}{*}{ Sinıf düzeyi } & 3. sınıf & 118 & 129.44 & 23.09 & \multirow{2}{*}{228} & -1.919 & .056 \\
\hline
\end{tabular}

aRehber öğretmen özel eğitim öz yeterlik ölçeği.

${ }^{*} p<.05$.

Yapılan bağımsız gruplar $\mathrm{t}$ testine göre, katılımcı kadınların ve erkeklerin özel eğitim öz-yeterlik puan ortalamaları arasında gözlenen farklar anlamlı bulunmamıştır $(t(231)=-.481, p>.05)$. Öte yandan kaynaştırma dersi alan ve kaynaştırma dersi almayan katılımcıların özel eğitim öz-yeterlik puan ortalamaları arasında gözlenen farklar kaynaştırma dersi alanların lehine anlamlıdır $(t(231)=3.207, p<.05)$. Bu farka ilişkin etki büyüklüğü ise Cohen 'in d'si ile hesaplanmıştır ve etki büyüklüğü küçük bulunmuştur (Cohen's $d=.04)$. Yapılan bağımsız gruplar $t$ testi sonuçlarına göre, üçüncü ve dördüncü sınıfta öğrenim görme durumuna göre özel eğitim öz-yeterlik puan ortalamaları arasında gözlenen farklar anlamlı bulunmamıştır $(t(228)=-1.919, p>.05)$.

\section{Nitel Bulgular}

Bu kısımda araştırmanın nitel bölümü olan özel eğitimde psikolojik danışma ve rehberlik hizmetleri yeterliliğine ilişkin bulgular yer almaktadır. Katılımcıların $39^{\prime}$ u $\left(\% 16.7, n_{\text {toplam }}=233\right)$ sunulan vaka ile ilgili hiçbir 
nitel soruya yanıt vermeyerek, "Fikrim yok" seçeneğini işaretlemiştir. En az bir soruya yanıt veren 185 katılımcıdan elde edilen veriler nitel analize alınmıştır $\left(\% 79.4, n_{\text {toplam }}=233\right)$. Dolayısıyla nitel verilerde katılımcı sayısı toplam 185 (\%100) olarak değerlendirilmiş ve bu aşamadan itibaren verilen yüzdeler bu sayı esas alınarak oluşturulmuştur. Katılımcılar bir soruda birden fazla kategoriye girecek yanıtlar verdiğinden yanıt sıklıklarının toplamı katılımcı sayısından fazladır. Bir başka deyişle bulgular kısmında katılımcıların sayısı değil, ifadelerin sayısı belirlenmiş ve sıklık $(f)$ olarak ifade edilmiştir. Elde edilen nitel veriler için her katılımcıya birer kod verilmiştir ve böylece katılımcı ifadeleri örneklendirilmiştir. Örneklendirilen ifadenin hangi tema ve kategori/alt kategoride olduğunun anlaşılması için katılımcı kodlarının yanında, tema sayısı ve kategori/alt kategorinin harf kodları verilmiştir (Örneğin, 1.tema, a kategorisi, ii alt kategorisi içinde değerlendirilen bir yanıt için 2-a-ii kodu). $\mathrm{Bu}$ kısımda her bir soruya verilen yanıtlar temalar, kategori ve alt kategoriler, yanıt sıklıkları $(f)$ olarak Tablo 3 , Tablo 4, Tablo 5 ve Tablo 6'da sunulmuştur.

\section{Tablo 3}

Tanı ve Değerlendirme İçin Kurumlara Başvuru ve Başvuruda İzlenen Yollar Hakkında Bulgular

\begin{tabular}{|c|c|c|}
\hline Temalar & Kategori ve alt kategoriler & $f$ \\
\hline \multirow{6}{*}{ 1. Yönlendirilecek kurum/uzman } & (a) RAM $^{\mathrm{a}}$ & 88 \\
\hline & (b) DKT veya odyolog ${ }^{\mathrm{b}}$ & 23 \\
\hline & (c) Doktor & 11 \\
\hline & (d) Özel eğitim kurumu & 10 \\
\hline & (e) Psikiyatrist & 5 \\
\hline & Toplam & 137 \\
\hline \multirow{13}{*}{ 2. Yönlendirmede izlenecek yol } & (a) Direkt olarak yönlendirme & 35 \\
\hline & (b) Öğrenci ile ilgili bilgi toplama ve ardından yönlendirme & \\
\hline & i. Öğretmenlerinden & 10 \\
\hline & ii. Özel eğitim çalışanlarından & 7 \\
\hline & iii. Ailesinden & 6 \\
\hline & iv. Gözlem yoluyla & 5 \\
\hline & v. Yazılı kaynaklardan & 2 \\
\hline & Toplam & 30 \\
\hline & (c) Öğrenci ile ilgili bilgi verme ve ardından yönlendirme & \\
\hline & i. Aileye & 14 \\
\hline & ii. Okul idaresine & 10 \\
\hline & iii. Öğretmenlere & 1 \\
\hline & Toplam & 25 \\
\hline 3. Fikrim yok & & 20 \\
\hline \multirow[t]{3}{*}{ 4. Diğer } & (a) Tanı-değerlendirme için test yapma & 2 \\
\hline & (b) Bilgi eksiğini yansıtan açıklamalar & 10 \\
\hline & Toplam & 12 \\
\hline
\end{tabular}

${ }^{a}$ Rehberlik ve araştırma merkezi. ${ }^{b}$ Dil ve konuşma terapisti.

Birinci soruya verilen yanıtlar "Tanı ve değerlendirme için kurumlara başvuru ve başvuruda izlenen yollar" hakkındadır ve katılımcıların $165^{\prime}$ 'i $(\% 89.2, n=185)$ bu soruyu yanıtlamıştır. Elde edilen yanıtlar 1. Yönlendirilecek kurum, 2. Yönlendirmede izlenecek yol, 3. Fikrim yok ve 4. Diğer şeklindedir. Katılımcıların yönlendirilecek kuruma verdiği yanıtlar (a) RAM, (b) Dil ve Konuşma Terapisti (DKT) veya odyolog, (c) Doktor, (d) Özel eğitim kurumu ve (e) Psikiyatrist şeklindedir. Bu soruya ilişkin yanıtlardan bazıları şöyledir:

“K9: RAM'a yönlendirirdim (1-a), K39: Dil ve konuşma terapistine yönlendiririm (1-b), K19: (Dil ve konuşma bozukluğunun) Fiziksel bir altyapısı olup olmadığını görmek için doktora yönlendirirdim (1-c), K95: Özel eğitim merkezine başvururum (1-d), K87: Çocuk ve ergen psikiyatristine sevk ederdim (1-e).”

Katılımcıların tanı ve değerlendirme için başvuruda izlenecek yollar sorusuna verdikleri yanıtlar (a) Direkt olarak yönlendirme (b) Öğrenci ile ilgili bilgi toplama ve ardından yönlendirme (i. Öğretmenlerinden, ii. Özel eğitim çalışanlarından, iii. Ailesinden, iv. Gözlem yoluyla ve v. Yazılı kaynaklardan), (c) Öğrenci ile ilgili bilgi verme ve ardından yönlendirme (i. Aileye, ii. Okul idaresine ve iii. Öğretmenlere) ve şeklindedir. Bu soruya ilişkin yanıtlardan bazıları şöyledir:

“K98: Gerekli evraklarla direkt RAM’a yönlendiririm (2-a), K23: Öğretmenleriyle görüşerek bilgi toplardım ve şüphem güçlenmişse RAM'a yönlendirirdim (2-b-i), K44: RAM'a başvurmadan önce ailesi ve okul müdürüne bilgi verirdim (2-c-i ve 2-c-ii).” 
Katılımcılardan alınan bazı ifadeler ise (a) Tanı-değerlendirme için test yapma, (b) Bilgi eksiğini yansıtan açıklamalar kapsamındadır. Katılımcılardan bu soruya ilişkin alınan yanıtlardan bazıları şu şekildedir:

"K111: Diksiyon dersi alabileceği kurumları araştırırdım (4-b), K114: Disleksi derneğine yönlendiririm (4-b)."

Tablo 4

Öğrenci İçin Yapılacak Eğitsel, Mesleki, Kişisel/Sosyal Rehberlik Çalışmaları Hakkında Bulgular

\begin{tabular}{llc}
\hline \multicolumn{1}{c}{ Temalar } & \multicolumn{1}{c}{ Kategori ve alt kategoriler } & $f$ \\
\hline & (a) Eğitsel çalışmalar planlama & 24 \\
1. Eğitsel rehberlik & (b) Derslere uyum çalışmaları & 23 \\
& (c) Özel eğitim kurumlarıla iş birliği & 15 \\
& (d) BEP çalışmaları & 12 \\
& (e) Okuma etkinlikleri & 11 \\
& Toplam & 85 \\
2. Mesleki rehberlik & (a) Kariyer danışması & 9 \\
& (b) Bireyin kendini tanıması çalışmaları & 5 \\
& Toplam & 14 \\
& (a) Bireysel çalışmalar & 67 \\
3. Kişisel/sosyal rehberlik & i. Psikolojik danışma/bireysel görüşme & 2 \\
& ii. Nefes/konuşma egzersizi & 16 \\
(b) Grup çalışmaları & 23 \\
i. Grup rehberliği/grupla psikolojik danışma & 10 \\
4. Hak savunuculuğu & ii. Akran ilişkileri/sosyal beceri geliştirme çalışmaları & 2 \\
5. Fikrim yok & iii. Sosyal kabul için sınıf içi çalışmalar & 120 \\
& iv. Drama çalışmaları & 6 \\
6. Diğer & Toplam & 12 \\
& & 17
\end{tabular}

${ }^{\mathrm{a} B i r e y s e l l e s ̧ t i r i l m i s ̧ ~ e g ̆ i t i m ~ p r o g r a m ı . ~}{ }^{\mathrm{b}}$ Dil ve konuşma terapisti.

İkinci soruya verilen yanıtlar öğrenci için yapılacak eğitsel, mesleki, kişisel/sosyal rehberlik çalışmaları hakkındaki bulgular ile ilgilidir. Katılımcıların yanıtları 1. Eğitsel rehberlik, 2. Mesleki rehberlik, 3. Kişisel/sosyal rehberlik, 4. Hak savunuculuğu, 5. Fikrim yok ve 6. Diğer şeklindedir. Eğitsel rehberlik kapsamında yapılacak çalışmalar (a) Eğitsel çalışmalar planlama, (b) Derslere uyum çalışmaları, (c) Özel eğitim kurumlarıyla iş birliğgi, (d) BEP çalışmaları ve (e) Okuma etkinlikleri şeklinde kategorize edilmiştir. Mesleki rehberlik kapsamında yapınacak çalışmalar (a) Kariyer danışması, (b) Bireyin kendini tanıması çalışmaları olarak kategorize edilmiştir. Kişisel/sosyal rehberlik ise (a) Bireysel çalışmalar (i. Psikolojik danışma/bireysel görüşme, ii. Nefes/konuşma egzersizi), (b) Grup çalışmaları (i. Grup rehberliği/grupla psikolojik danışma, ii. Akran ilişkileri/sosyal beceri geliştirme çalışmaları, iii. Sosyal kabul için sınıf içi çalışmalar, iv. Drama çalışmaları) şeklinde sıralanmaktadır. $\mathrm{Bu}$ soruya ilişkin katılımcı yanıtlarından bazıları aşağıda örneklendirilmiştir:

“K13: Eğitsel olarak RAM’a başvurur ve onların verdiği planla çalışmaları uygulardım (1-d), K32: Eğitsel anlamda, BEP için çalışma başlatırdım (1-e), K14: İlk etapta kişisel/sosyal rehberlik yapardım. Bunu da psikolojik danışma hizmetiyle yapardım (3-a-i), K80: Bir grup rehberliği ya da grupla psikolojik danışmaya davet ederdim (3-b-i)."

Katılımcılar aynı zamanda eğitsel, mesleki, kişisel/sosyal rehberlik kapsamında yapabilecekleri çalışmalarla ilgili soruya hak savunuculuğu kapsamına alınabilecek yanıtlar vermişlerdir. Bu yanıtların örneği aşağıdaki gibidir:

“K20: Arkadaşları arasında dışlanmaması için okulumdaki öğrencilere ve farkındalık kazanmaları için öğretmenlere konferans yapar ve alanındaki uzman kişileri davet ederdim (4).” 
Katılımcıların verdikleri bazı yanıtlar sadece “eğitsel, mesleki, kişisel/sosyal rehberlik yapmak” şeklinde ifade edilmiş ancak bu ifadelerde ne gibi etkinlikler yapılacağına dair bir açıklama yapılmamıştır. Verilen bu yanıtlar içeriğin belirsizliğinden dolayı ayrı değerlendirilmiştir. Diğer yanıtlar ise (b) Yönlendirme (DKT, odyolog vb.), (c) Rehberlik etkinliklerinde uyarlama çalışmaları, (d) Bilgi eksiğini yansıtan açıklamalar şeklinde kategorize edilmiştir. Bu yanıtların bazı örnekleri aşağıda verilmiştir:

"K49: Eğitsel-kişisel rehberlik yaparım (6-a), K104: Grup etkinlikleri yaparken sözlü yapılacak etkinliği Selin'e yazılı materyalle sundururdum (6-c), K4: Dil ve konuşma terapistine yollardım. Böylece eğitsel, mesleki ve sosyal olarak problem oluşmazdı (6-d), K18: BEP hazırlarım (6-d).”

Tablo 5

Özel Gereksinimli Öğrencinin Ailesine Yönelik Rehberlik Çalışmaları Hakkında Bulgular

\begin{tabular}{llc}
\hline \multicolumn{1}{c}{ Temalar } & \multicolumn{1}{c}{ Kategoriler } & $f$ \\
\hline & (a) Öğrencinin durumu/DKBa ile ilgili & 73 \\
1. Aileyi bilgilendirme & (b) Evde öğrencinin gelişimine destek çalışmaları ile ilgili & 52 \\
& (c) Çocuklarına nasıl davranmaları gerektiği ile ilgili & 28 \\
& Toplam & 153 \\
& (a) Aile görüşmeleri planlama & 31 \\
2. Aile katılımını sağlama & (b) Diğer velilerden destek sağlama & 3 \\
& (c) Ev ziyaretleri planlama & 3 \\
3. Aileyi özel eğitim kurumlarına yönlendirme & Toplam & 37 \\
4. Hak savunuculuğu & & 21 \\
5. Fikrim yok & & 17 \\
6. Diğer & & 11 \\
& & 4 \\
\hline
\end{tabular}

${ }^{a}$ Dil ve konuşma bozukluğu.

Üçüncü soruya verilen yanıtlar özel gereksinimli öğrencilerin ailelerine yönelik çalışmalar hakkındaki bulgular ile ilgilidir. Katılımcı ifadelerinin en sık olanları 1. Aileyi bilgilendirme: (a) Öğrencinin durumu/DKB ile ilgili, (b) Evde öğrencinin gelişimine destek çalışmaları ile ilgili, (c) Çocuklarına nasıl davranmaları gerektiği ile ilgili. 2. Aile katılımını sağlama: (a) Aile görüşmeleri planlama, (b) Diğer velilerden destek sağlama, (c) Ev ziyaretleri planlama, 3. Aileyi özel eğitim kurumlarına yönlendirme şeklindedir. Bu yanıtlardan bazıları aşağıdaki gibidir:

“K83:Okulda verilen eğitimi evde destekleme hakkında neler yapabileceklerini anlatırdım (1-b), K34: Selin'in hem psikolojik hem fizyolojik sağlı̆̆ının iyi olması için ona nasıl davranacaklarına ilişkin bilgilendirme yapardım (1-c), K101: Aileyle iletişim halinde olurum. Belli aralıklarla aile görüşmeleri planlarım (2-a), K84: Alenin süreçte desteğinin önemli olduğu ile ilgili görüşür mutlaka sürece dâhil ederdim (2-a)."

Katılımcılar aynı zamanda ailelere yönelik rehberlik çalışmaları ile ilgili soruya hak savunuculuğu kapsamına alınabilecek yanıtlar vermişlerdir. Dolayısıyla katılımcıların yanıtlarını 4. Hak savunuculuğu, 5. Fikrim yok ve 6. Diğer: (a) Müşavirlik yaparım ve (b) Bilgi eksikliğini yansıtan açıklamalar izlemektedir. Bu kapsamda verilen bazı yanıtlar aşağıdaki gibidir:

"K98: Eksikliğin engele dönüşmemesi için yasal olarak yapabileceklerini anlatırdım (4), K131: Çocuklarının ve onların yasal haklarını aktarırdım (4), K142:Ailesine müşavirlik yaparım (6-a), K40: Bu durumun tedavi edilebileceğine ilişkin telkinlerde bulunurum (6-b), K94: Eğer çocuğunuzda böyle bir durum varsa basit tedavilerle iyileştirilebilir derdim (6-b).” 
Tablo 6

Özel Gereksinimli Öğrencinin Öğretmenlerine Yönelik Rehberlik Çalışmaları Hakkında Bulgular

\begin{tabular}{llc}
\hline \multicolumn{1}{c}{ Temalar } & \multicolumn{1}{c}{ Kategoriler } & $f$ \\
& (a) Öğrencinin durumu/DKBa hakkında & 56 \\
& (b) Sinıf içi uyum çalışmaları hakkında & 43 \\
1. Öğretmeni bilgilendirme & (c) Öğrenciye nasıl davranılması gerektiği hakkında & 40 \\
& (d) Öğrencinin eğitsel gelişimi hakkında & 34 \\
& (e) BEPb ile ilgili & 15 \\
& (f) Öğrencinin değerlendirilmesi ile ilgili & 3 \\
2. Öğretmenle iş birliği halinde olma & Toplam & 191 \\
3. Hak savunuculuğu & & 19 \\
4. Fikrim yok & & 13 \\
5. Diğer & (a) Bilgi eksikliğini yansıtan açıklamalar & 19 \\
\hline a & & 11
\end{tabular}

${ }^{\mathrm{a} D i l}$ ve konuşma bozukluğu. ${ }^{\mathrm{b}}$ Bireyselleştirilmiş eğitim programı.

Dördüncü soruya verilen yanıtlar özel gereksinimli öğrencilerin öğretmenlerine yönelik çalışmalar hakkındaki bulgular ile ilgilidir. Katılımcı ifadelerinin en sık olanları 1. Öğretmeni bilgilendirme: (a) Öğrencinin durumu/DKB hakkında, (b) Öğrencinin sınıf içi uyumunu attıracak çalışmalar hakkında, (c) Öğrenciye nasıl davranması gerektiği ile ilgili, (d) Öğrencinin eğitsel gelişimi hakkında, (e) BEP ile ilgili ve (f) Öğrencinin değerlendirilmesi ile ilgili, 2. Öğretmenle iş birliği halinde olma şeklindedir. Bu kategorideki katılımcı ifadelerinden bazıları şu şekildedir:

"K12: Özel gereksinimli bir öğrenciye nasıl davranması gerektiğini anlatırdım. Onu görmezden gelmemesini ve sabırlı olmasını söylerdim (1-c), K30: Her zaman öğretmeniyle iş birliğiyle Selin'in durumunu takip ederdim (2).”

Katılımcılar aynı zamanda öğretmenlere yönelik rehberlik çalışmaları ile ilgili soruya hak savunuculuğu kapsamına alınabilecek yanıtlar vermişlerdir. Katılımcıların yanıtlarını 3. Hak savunuculuğu, 4. Fikrim yok ve 5. Diğer: (a) Bilgi eksikliğini yansıtan açıklamalar izlemektedir. Bu kapsamda verilen bazı yanıtlar aşağıdaki gibidir:

“K102: Öğretmenlerini ve tüm okul personelini bilgilendiririm (3), K27: Hiçbir fikrim yok (4), K89: Onun için hazırladığım BEP planına uygun hareket etmesini isterdim (5-a), K68: Öğrenciye uygun BEP hazırlayarak gerekli düzenlemelerin yapılmasını ve bunun yasal bir zorunluluk olduğunu ifade ederdim (3)."

\section{Tartışma}

$\mathrm{Bu}$ araştırmanın amacı okul psikolojik danışmanı adaylarının özel eğitim öz-yeterlik algılarının ve yeterliliklerinin araştırılmasıdır. Bu amaçla katılımcıların özel eğitim öz-yeterlik düzeyleri belirlenmiş ve özel eğitim öz-yeterlik algılarının kimlik cinsiyetlerine, kaynaştırma dersi alıp almamalarına ve sınıf düzeylerine göre farklı olup olmadığ 1 araştırılmıştır. Aynı zamanda katılımcıların özel eğitim ile ilgili yeterliliklerinin incelenmesi için öğrenciyi tanı ve değerlendirme için yönlendirme, öğrencinin gelişimi için eğitsel, kişisel/sosyal ve mesleki rehberlik çalışmaları, özel gereksinimli çocuğun ailesi ve öğretmenlerine yönelik müşavirlik hizmeti kapsamında verebilecekleri hizmetlere yönelik yeterlilikleri nitel yolla incelenmiştir.

Elde edilen bulgulara göre, katılımcıların özel eğitim öz-yeterlik algılarının puan ortalamasının orta düzeyde olduğu bulunmuştur. Türkiye'de yapılan araştırmalarda hem okul psikolojik danışmanlarının (Aksoy \& Diken, 2009b) hem de okul psikolojik danışmanı adaylarının özel eğitim öz-yeterlik düzeylerinin orta düzeyde (Deniz, 2016; Sönmez vd., 2020) veya orta düzeyin biraz altında (Yüksel vd., 2012) bulunmuştur. Dolayısıyla alanyazının bu araştırmadaki bulguyla paralel olduğu görülmektedir. Bu çalışmada ve yapılan diğer çalışmalarda özel eğitim öz-yeterlik algısının yüksek bulunmadığı dikkat çekmektedir. Bu durumun gerekçelerinden biri özel eğitimle ilgili sınırlı düzeyde eğitim alınması olabilir. Özel eğitim ve kaynaştırma derslerinin YÖK'ün 2018 yılındaki düzenlemesinden önceki içerikleri incelendiğinde öğretmenlik programlarında "ortak dersler" kapsamında oldukları ve içeriklerinin eğitim fakültesinin her bölümünde hemen hemen aynı olduğu görülmektedir. Örneğin bir üniversitede RPD ve Sosyal Bilgiler Öğretmenliği programlarında özel eğitim dersinin içeriği aynı ve "özel eğitimin tanımını yapma ve temel ilkelerini bilme, farklı türdeki engelleri tanıyabilme, farklı özel gereksinimli öğrencilerin özellikleri ve eğitsel ihtiyaçlarını tanımak” şeklindedir (Örneğin, Gazi Üniversitesi Bilgi 
Paketi, 2020a, 2020b). Bazı programlar bundan farklı olarak "çeşitli gruplardaki özel eğitime ihtiyaç duyan çocukların tespiti, eğitim ve tedavisinde kendi meslek alana uygun rolleri açıklar” şeklinde öğrenme çıktıları da barındırmaktadır (Örneğin, Hacettepe Üniversitesi Ders Kataloğu, 2020a). Yine RPD lisans programlarındaki özel eğitim dersi içerikleri incelendiğinde "eğitim alanında uygulanması gereken gelişim destek programları ve psikolojik danışma ve rehberlik hakkında bilgilendirmek” gibi amaçlar bulunmaktadır (Örneğin, Hacettepe Üniversitesi Ders Kataloğu, 2020b). Dolayısıyla açılan ortak özel eğitim dersi için bazı programlarda ders amaçlarının farklılaştığı görülürken bazı programlarda branşlara göre sınırlı sayılabilecek uyarlama yapıldığı izlenimi edinilmektedir. Dikkat çeken bir başka husus açılan derslerin kuramsal olmasıdır. Oysa özel eğitimle ilgili deneyim düzeyi arttıkça öz-yeterlik algısının da arttığı çeşitli araştırmalarla ortaya konmuştur (Aksoy \& Diken, 2009b). Ayrıca yapılan bir araştırmada okul psikolojik danışmanları, özel eğitim konusunda aldıkları eğitiminin sınırlılığına değinmiş ve uygulamalı derslere ihtiyaç duyduklarını belirtmiştir (Sütçü, 2007). Buradan hareketle lisans düzeyinde özel eğitimle ilgili okul psikolojik danışmanlarının görevlerine ilişkin uygulamalı dersler verilmesi okul psikolojik danışmanı adaylarının özel eğitim öz-yeterlik algı düzeyini arttırması olasıdır.

Bulgulara göre katılımcıların kimlik cinsiyetine göre özel eğitim öz-yeterlik puanları arasında anlamlı fark yoktur. Bu bulgu alanyazındaki bazı çalışmaların bulgularıyla paralel iken (Deniz, 2016; Sönmez vd., 2020); bazı çalışmaların bulgularıyla çelişki göstermektedir (Yüksel vd., 2012). Yüksel vd., (2012), kimlik cinsiyeti açısından anlamlı fark ortaya koyan çalışmalarında bulunan farkın etki büyüklüğünün küçük olduğu sonucu elde etmiştir. Dolayısıyla kimlik cinsiyetinin kadın veya erkek olmasının özel eğitim öz-yeterlik puan ortalamasında büyük bir etkisi olmadığı söylenebilir. Bu değişkenler arasındaki farkın ulusal ölçekte tarama veya meta-analiz çalışmalarıyla netleştirilebileceği düşünülmektedir.

$\mathrm{Bu}$ araştırmanın bulgularından biri de 3. ve 4. sınıfa devam eden RPD öğrencilerinin özel eğitim özyeterlik puan ortalamaları arasında anlamlı fark olmamasıdır. Alanyazındaki benzer araştırmalarda, 2. sınıfa devam edenlerle 3. ve 4. sınıfa devam eden öğrencilerin özel eğitim öz-yeterlikleri arasında anlamlı fark olduğu; ancak 3. ve 4. sınıfa devam edenler arasında böyle bir fark olmadığı gözlenmiştir (Deniz, 2016). Yine yapılan bir araştırmada 4. sınıf öğrencilerinin özel eğitim öz-yeterlik puan ortalamalarının 1. sınıf öğrencilerininkinden; 2. sınıf öğrencilerinin 1. sınıf öğrencilerininkinden; 3. sınıf öğrencilerinin 2. sınıf öğrencilerininkinden yüksek olduğu ortaya konmuştur. Belirtilen farkların etki değerinin küçük olduğu bulgulanmıştır (Yüksel vd., 2012). Önceki araştırmalarda sınıf düzeyi arttıkça özel eğitim öz-yeterlik algısının arttığı belirtilse de (Yüksel vd., 2012), 3. sınıf öğrencileri ile 4. sınıf öğrencilerinden elde edilen puanlar arasında anlamlı bir fark olduğu bulgular arasında bulunmamaktadır. Bu araştırmada ise, katılımcıların neredeyse tamamının (\%98.3, $n=229)$ özel eğitim dersini ve bir kısmının kaynaştırma dersini $(\% 31.8, n=74)$ almış ve tamamlamış olmasından dolayı 3. ve 4 . sınıf düzeylerindeki öğrencilerin arasında özel eğitim öz-yeterliği bakımından fark olmadığı düşünülmektedir. Buradan hareketle, özel eğitim öz-yeterlik algısı düzeyinde öğrenciler arasında farklılık olup olmadığı değerlendirilirken, konu ile ilgili alınan derslerin göz önünde bulundurulması gerektiği düşünülmektedir.

Çalışmanın önemli bulgularından biri de "kaynaştırma" dersi alan ve almayan okul psikolojik danışmanı adaylarının özel eğitim öz-yeterliği puan ortalamaları arasındaki fark kaynaştırma dersi alanların lehine anlamlı bulunmasıdır. Bir başka deyişle kaynaştırma dersi alanların özel eğitim öz-yeterlik algısı, kaynaştırma dersi almayanlarınkinden yüksektir. Lisans düzeyindeki “Özel eğitim”, "Kaynaştırma” gibi derslerde okul psikolojik danışmanı adaylarına özel eğitim hakkında bilgilendirme yapılması beklenmektedir. Yüksek öz-yeterliğin eğitim düzeyiyle olan pozitif yönlü bağlantısı düşünüldüğünde (Yam \& İlhan, 2016); özel eğitimle ilgili daha sınırlı düzeyde eğitim almış olanların öz-yeterliğinin, daha çok eğitim alanlarınkinden düşük olması beklendik bir sonuçtur.

Çalışmanın nitel bulgularına bakıldığında katılımcıların bir kısmının (\%16.7, $n=39)$ vaka ile ilgili sorulara dair hiçbir fikri olmadığını belirttiği görülmektedir. Fikri olmadığını belirten katılımcıların \%97.4'ünün $(n=38)$ özel eğitim dersi aldığı görülmektedir. Fikri olmadığını belirtenlerin sadece \%17.9'u $(n=7)$ kaynaştırma dersi almış durumdadır. Yanıt veren katılımcıların ise $(\% 83.3, n=185)$ neredeyse tamamı özel eğitim dersi almış olmakla birlikte $(\% 98.9, n=183)$, yarısından azı kaynaştırma dersi almıştır $(\% 34.6, n=64)$. Dolayısıyla hem özel eğitim hem de kaynaştırma dersi alanların nitel sorulara daha yüksek oranda fikir yürütebildiği söylenebilir. Buradan hareketle, vaka ile ilgili fikir sahibi olunmaması durumunun sebeplerinden biri katılımcıların aldıkları özel eğitim dersinin tek başına bu vakadaki ilgili sorulara yanıt vermek için gerekli bilgi ve becerileri kazandırmaya yeterli gelmemesi olabilir. Diğer gerekçeler ise nitel veri toplama sürecinin sınırlılıklarından kaynaklanıyor olabilir. Örneğin, katılımcılar bilgilendirilmiş onam formunu imzalasa bile sorulara yanıt vermeye gönüllü olmadığından fikirleri olmadığını belirtmiş olabilir veya verilen vakanın sadece tek bir özel gereksinim türüne odaklanması sebebiyle yanıtlayamamış olabilirler. Bir başka deyişle, katılımcılar bir başka vaka ile ilgili 
fikir yürütebilir durumda olabilir. Dolayısıyla bu bulgular nitel araştırmanın sınırlılıkları dikkate alınarak yorumlanmıştır.

Nitel sorulara verilen yanıtların ilk bulgusu "Tanı ve değerlendirme için kurumlara başvuru ve başvuruda izlenen yollar" hakkındaki yanıtlardır. Yazılanların büyük bir kısmı RAM'a $(f=88)$; dil ve konuşma terapisti veya odyoloğa $(f=23)$, doktora $(f=11)$, özel eğitim kurumuna $(f=10)$, psikiyatriste $(f=5)$ yönlendirme ifadelerini barındırmaktadır. Araştırmanın yapıldığı dönemde geçerli olan Millî Eğitim Bakanlığı Rehberlik Hizmetleri Yönetmeliği (MEB, 2018) incelendiğinde (madde 34/1) okul psikolojik danışmanının görevlerinden birinin "Özel ĕgitim ihtiyacı olan ögrenciler ve ailelerine yönelik eğitim hizmetlerinin yürütülmesinde ilgili kişi, kurum ve kuruluşlarla iş birliği yapar. ” olduğu görülmektedir. Okul psikolojik danışmanının özel eğitimle ilgili kurullarda yer alarak, diğer kişi ve kurumlarla işbirliği içinde çalışması gerektiği Özel Eğitim Hizmetleri Yönetmeliğinde de (2020a) belirtilmiştir. Dolayısıyla verilen yanıtlar, okul psikolojik danışmanlarının görevleri bakımından yasal süreçle paraleldir. Ancak bazı yanıtların öğrenciyi diksiyon dersine veya disleksi derneğine göndermek şeklinde olduğu görülmüştür. Öğrencinin sorunu tespit edilmemişken ve vakada belirtildiği üzere öğrenciyle ilgili dil ve konuşma bozukluğu şüphesi varken, bu tür yönlendirmeler ilk aşamada atılması gereken adımlardan sayılmayabilir.

Yönlendirilmede izlenecek yola ilişkin yanıtlarda ifadelerin büyük bir kısmının direkt olarak yönlendirme $(f=35)$ şeklinde ifade edildiği görülmüştür. Alanyazında okul psikolojik danışmanlarının öğrenciyle ilgili herhangi bir düzenleme yapılmaksızın RAM'a yönlendirmeyi bilgi eksikliklerinden dolayı tercih ettiği ortaya koyulmuştur (Sütçü, 2007). Bu çalışmada da katılımcılar bilgi eksiklikleri nedeniyle bu yanıtı en sık dile getirmiş olabilirler. Öte yandan, alanyazına göre okul psikolojik danışmanlarının sınıf öğretmeniyle işbirliği ile sınıf içinde çeşitli düzenlemeler yapma yoluna girmesi, öğrencilerin gereksiz bir değerlendirmeye alınmasını engelleyebilmektedir (Kirk vd., 2006) (akt., Kargın, 2007). Öğrencileri RAM'a yönlendirmeden önce gönderme öncesi bir süreç başlatılmalıdır. Böylece yoğun olarak özel eğitime gereksinim duymayan öğrencilerin sınıfa katılımı sağlanabilir (Heward, 2006). Yönlendirmede izlenecek yol ile ilgili bazı ifadelerin ise öğrenci ile ilgili çeşitli kaynaklardan (örneğin, ailesinden, gözlem yoluyla vb.) bilgi toplama ve ardından yönlendirme $(f=30)$ ve öğrenci ile ilgili çeşitli kaynaklara bilgi verme (örneğin, aileye, öğretmenlere vb.) ve ardından yönlendirme $(f=$ 25) şeklinde olduğu görülmüştür. Özel Eğitim Hizmetleri Yönetmeliğinde (MEB, 2020a) 7. maddenin b bendinde bireylerin eğitsel değerlendirmesi ve tanılamasıyla ilgili ilk başvurunun, okul yönetimi, veli veya zihinsel yetersizliği olmayan 18 yaşından büyük bireyin kendisi tarafından RAM'a yapılacağı belirtilmektedir. Dolayısıyla verilen vakada bahsedilen ilkokul öğrencisinin yönlendirilmesinde öncelikle aileye ve okul yönetimine bilgi vermek ve ardından yönlendirme işlemlerini başlatmak uygun bir adım olarak düşünülebilir. Yine katılımcıların öğrenciyle ilgili bilgi toplama ve ardından gerekli ise yönlendirme yaklaşımının olması da önemli bir bulgudur. $\mathrm{Bu}$ yolla öğrencinin özel eğitime ihtiyacı olup olmadığına dair görüşler işbirliği içinde netleştirilebilir. Katılımcıların bazıları ise öğrenciyi yönlendirmek yerine tanı-değerlendirme için test yapacaklarını belirtmiştir $(f$ =2). Bilinmektedir ki tüm test ve değerlendirmeler bu uygulamalarla ilgili eğitim almış uzmanlarca yapılmalıdır (Turnbull vd., 2007). Ancak RPD eğitim programlarında özel gereksinimli öğrencilerin tanılanmasına yönelik testleri uygulama konusunda herhangi bir ders bulunmamaktadır. Bu nedenle resmi olarak geçerli ve uygulama yetkisi veren bir eğitim almadıkları sürece okul psikolojik danışmanlarının yetkinlik sınırlarını aşan uygulamalar içinde olmaması lisans eğitim süreçlerinde vurgulanmalıdır.

Öğrenci için yapılacak eğitsel, mesleki ve kişisel/sosyal rehberlik çalışmalarına dair bulgular her bir problem alanlarına göre sınıflandırılmıştır. Yanıtlar genel olarak incelendiğinde katılımcıların en sık kişisel/sosyal rehberlik $(f=120)$, ardından eğitsel rehberlik $(f=85)$ ve en az sıklıkta mesleki rehberlik $(f=14)$ kapsamındaki çalışmalara yer verdiği dikkat çekmektedir. Bu durumun sebebi, RPD lisans programlarında en çok vurgulanan ve alınan derslerle gerek kuramsal gerekse uygulamalı olarak ayrıntılandırılan hizmetin bireysel psikolojik danışma ve grupla psikolojik danışma olması olabilir. YÖK tarafından standartlaştırılan program öncesi verilen lisans eğitimlerinde mesleki rehberlik/kariyer danışması ile ilgili biri kuramsal biri uygulamalı olmak üzere yalnızca iki zorunlu derse yer verildiği dikkat çekmektedir (Örneğin, Hacettepe Üniversitesi Ders Kataloğu, 2019). Bu sebeple katılımcılar en sıklıkla kişisel/sosyal rehberlik kapsamında değerlendirilen çalışmalara yer vermiş olabilirler.

Eğitsel rehberlik kapsamında en çok ifade edilen görüşler eğitsel çalışmalar planlama $(f=24)$, derslere uyum çalışmaları $(f=23)$, özel eğitim kurumlarıyla iş birliği $(f=12)$, BEP çalışmaları $(f=12)$ ve okuma etkinlikleri $(f=11)$ şeklindedir. Verilen yanıtların çoğunun, özel gereksinimin türüne bakılmaksızın özel gereksinimli her öğrenci için uygulanabilir yanıtlar olduğu dikkat çekmektedir. Yanıtların içerikleri incelendiğinde çoğunun RAM ve öğrencinin öğretmenleriyle işbirliği içinde hareket etmeye vurgu yaptığı görülmüştür. Öte yandan, bu işbirliğinin yansıtılmadığı ve okul psikolojik danışmanının yetkinlik ve görev sınırlarını aşan ifadeler bilgi 
eksikliğini yansıtan ifadelerden sayılmıştır. Örneğin katılımcılardan bazıları "BEP hazırlarım” şeklinde ifadeler kullanmıştır. Alanyazına bakıldığında RPD öğrencilerinin özel eğitim dersine ilişkin kazanımlarının incelendiği bir araştırmada da (Kösterelioğlu \& Baytemir, 2016), dersi alan öğrencilerin benzer ifadeler kullandığ1 görülmüştür (Örneğin, "BEP hazırlarım”). Ancak, araştırmanın yapıldığı dönemde geçerli olan Millî Eğitim Bakanlığı Rehberlik Hizmetleri Yönetmeliği incelendiğinde (MEB, 2018, madde 19/k) "Özel eğitim ihtiyacı olan öğrencilerin ĕ̆itim ihtiyaçlarının karşılanması amacıyla bireyselleştirilmiş ĕgitim programı geliştirme ekibinde rehberlik hizmetlerini yürütmek üzere görev alır." ifadesinin yer aldığı görülmektedir. Güncellenen Rehberlik ve Psikolojik Danışma Yönetmeliğinde ise, BEP geliştirme komisyonuna dair bir açıklama yer almamaktadır (MEB, 2020b). Öte yandan bu komisyonun üyeleri ve görevleri Özel Eğitim Hizmetleri Yönetmeliğinde tanıtılmıştır (MEB, 2020a). Güncellenen yönetmeliklerde okul psikolojik danışmanlarının BEP geliştirme birimindeki görevi özel olarak tanımlanmasa da, bilinmektedir ki BEP hazırlamak okul psikolojik danışmanının tek başına alacağı bir sorumluluk değildir ve eğitsel anlamda her branş için özel bilgi ve beceriler gerektirdiğinden yetkinlik sınırlarını da aşan bir uygulamadır. Rehberlik ve Psikolojik Danışma Hizmetleri Etik Yönergesinde, yetkinlik ilkesi kapsamında okul psikolojik danışmanlarının mesleki yeterliklerini aşan uygulamaları gerçekleştirmemesi gerektiği vurgulanmıştır (MEB, 2020c). Buradan hareketle, RPD öğrencilerinin özel eğitim hakkında yasal görev ve sorumlulukları hakkında ve de yetkinlik sınırları içindeki uygulamaları ayırt etmesi konusunda bilgilendirilmesi gerektiği söylenebilir.

Mesleki rehberlik kapsamında en sık ifade edilen görüşler kariyer danışması yapma $(f=9)$, bireyin kendini tanımasına dair çalışmalar $(f=5)$ şeklindedir. Görülmüştür ki mesleki rehberlik bu soruda en az yanıt yazılan alandır. Öte yandan, rehberlik hizmetlerinde temel alınan yapısalcılık yaklaşımına göre mesleki rehberlik hizmetleri tüm öğrencilere yöneliktir (Yeşilyaprak, 2016). Dolayısıyla mesleki rehberlik hizmetleri özel gereksinimli öğrencileri de kapsamaktadır. Katılımcıların mesleki rehberliğe daha az odaklanmasının sebebi, lisans düzeyinde alınan eğitimin daha çok kişisel/sosyal rehberliğe hizmet edecek nitelikte olması olabilir. Elde edilen sınırlı sayıdaki ifade incelendiğinde mesleki rehberlikle ilgili verilen bazı yanıtların sosyal adalete aykırı ifadeler içerdiği dikkat çekmiştir. Bazı katılımcılar "Öğrencilerin yapabileceği ve yapamayacă̆ meslekleri anlaması için kendini tanımasını sağlarım" şeklinde ifadeler kullanmıştır. Ancak tıpkı psikolojik danışma hizmetinin kültüre duyarlı olması gerektiği gibi (Buyruk-Genç \& Yüksel-Şahin, 2018) kariyer danışması hizmetleri de kültüre duyarlı ve hak temelli ilerlemelidir. Dolayısıyla kariyer danışmasının ve mesleki rehberliğin hedefi öğrencilerin neyi yapıp neyi yapamayacağının belirlenmesi değildir. Aksine, özel gereksinimli öğrencilerin tüm ihtiyaçlarına ulaşabilmesi için eğitsel, mesleki, kişisel/sosyal ihtiyaçlarının fark edilip karşılanması gerekir (Myers, 2005). Bireyler engel ve hastalıklar söz konusu olduğunda kariyer gelişimlerini bu engel/hastalık üzerinden tanımlayabilirler (Niles vd., 2018). Oysa kariyer yapılandırması pek çok faktörden etkilenmektedir. Ĕ̆er özel gereksinimli öğrencilere hak temelli bir kariyer danışması/mesleki rehberlik hizmeti sunulursa, özel gereksinimli olmanın tek başına öğrencilerin kariyer engeline (career barriers) dönüşmemesi yolunda bir adım atılmış olur.

Özel gereksinimli öğrencinin ailesine yönelik yapılan çalışmalara ilişkin bulgulara bakıldığında en sık ifade edilenlerin aileyi bilgilendirme $(f=153)$, aile katılımını sağlama $(f=37)$ ve aileyi özel eğitim kurumlarına yönlendirme $(f=21)$ şeklinde olduğu görülmektedir. İlgili alanyazına göre özel eğitim veya kaynaştırma sürecine aile katılımının sağlanması kaynaştırma programlarının başarısını ve sonuçlarını etkilemektedir (Sucuoğlu, 1996). Ailelere yönelik yapılan bilgilendirmeler ve aile-okul etkileşiminin arttırılması için planlanan görüşmeler aile sürece katılımını arttırma işlevi görebilir. Alanyazında okul psikolojik danışmanlarının özel eğitim sürecinde aile katılımını sağlamada önemli bir rol üstlendiği belirtilmektedir (Cimsir \& Hunt, 2018). Dolayısıyla aile katılımına yönelik bulgular, katılımcıların gerekli ve önemli bir noktaya dikkat çektiğini düşündürmektedir. Öğrencinin durumu hakkında ailenin bilgilendirilmesi konusundaki yanıtlardan bazıları ise, çocukların ve ailenin sahip oldukları yasal haklara vurgu yaptığından hak savunuculuğu kapsamında değerlendirilebilir. Bu nedenle, doğrudan çocuğun ve ailenin haklarından bahseden ifadeler hak savunuculuğu olarak ele alınmıştır $(f=17)$. Alanyazında çocukların yararına hak savunuculuğunu yapabilecek yegâne kişinin genellikle okul psikolojik danışmanı olduğu belirtilmektedir (Erford vd., 2003) (akt., Owens vd., 2011). Dolayısıyla katılımcıların bir kısmının özel gereksinimli çocukların ve ailelerinin yasal haklarına vurgu yapması önemli bulunsa da bu konuya değinen ifadelerin görece az olması okul psikolojik danışmanı adaylarının hak savunuculuğu ve sosyal adalet konusunda bilinçlendirilmeye ihtiyaç duyduklarını düşündürmektedir.

Özel gereksinimli öğrencinin öğretmenlerine yönelik yapılacak rehberlik çalışmalarına ilişkin bulgulara bakıldığında en sık ifade edilenlerin öğretmeni bilgilendirme $(f=191)$ ve öğretmenle iş birliği halinde olma $(f=$ 19) şeklinde olduğu görülmektedir. Katılımcılar öğrencinin sınıf içi uyumunun arttıracak çalışmalar, öğrencinin 
eğitsel gelişimi için yapılması gerekenler, öğrenciye sınıf içinde nasıl davranılacağı ile ilgili, BEP ile ilgili, öğrencinin değerlendirilmesinde yapılacak uyarlamalarla ilgili öğretmenleri bilgilendirme yapılmasına değinmiştir. Alanyazına göre bir sınıfta özel gereksinimli öğrenci olduğunda, okul psikolojik danışmanları öğretmenle birlikte sınıf içi çalışmalar yapmayı ve iş birliği yaparak öğrenciyi takip etmeyi seçmektedir (Sütçü, 2007). Okul psikolojik danışmanı adaylarının öğretmenlere özel eğitimle ilgili bilgilendirme yapması ve eğitsel destek sunması özel eğitim hizmeti ekibinin bir parçası olmasıyla ilişkilidir. Araştırma sırasında geçerli olan Rehberlik Hizmetleri Yönetmeliği (MEB, 2017) incelendiğinde, okul psikolojik danışmanlarının özel gereksinimli öğrencilere verilen hizmetlerin takip edilmesi, öğrencilerin gelişiminin izlenmesi ve bu konuda öğretmenlere rehberlik edilmesi gibi görevlerinin olduğu görülmektedir. Bu bakımdan katılımcıların vurguladığı bilgilendirme ve işbirliğinin, okul psikolojik danışmanlarının görev tanımına uygun olduğu söylenebilir. Sözü edilen soruda da katılımcıların öğrencilerin haklarına ilişkin ifadeleri hak savunuculuğu kapsamında değerlendirilmiş̧tir $(f=13)$. Her ne kadar Türkiye'de özel gereksinimli çocukların hakları yasalarla korunma altına almış olunsa da bu hakların göz ardı edilebileceği veya okul yöneticisi ve öğretmenlerin bu haklardan haberdar olmayabileceği belirtilmektedir (Cimsir \& Hunt, 2018). Buradan hareketle okul psikolojik danışmanlarına özel gereksinimli öğrencilerin haklarını okulun diğer paydaşlarına hatırlatma ve duyarlılık oluşturma konusunda bir sorumluluk düştüğü söylenebilir. Nitekim 2020 yılında yayınlanan Rehberlik ve Psikolojik Danışma Hizmetleri Etik Yönergesinde de (2020c), psikolojik danışmanların duyarlılık ilkesiyle hareket ederek, özel gereksinimli öğrencilerin eğitim ihtiyaçlarına erişmesi için gayret göstermesi gerektiği ifadesi yer almaktadır. Alanyazında bu sorumluluğu bireysel düzeyde almaya gönüllü olan okul çalışanının da genellikle okul psikolojik danışmanı olduğu vurgulanmaktadır (Owens vd., 2011). Bulgulara göre özel gereksinimli çocuklar için sosyal adalet ve hak savunuculuğu konusunda ifadeler yer alsa da, bu ifadelerin yeterli oldukları söylenemez. Ailelerle ilgili bulgularda belirtildiği üzere, okul ortamında da hak savunuculuğu çalışmaları konusunda okul psikolojik danışmanı adaylarının bilinçlendirilmesi önemlidir.

Özetle, okul psikolojik danışmanı adaylarının özel eğitim öz-yeterlik algısı orta düzey bulunmuştur. Özel eğitim öz-yeterliği kaynaştırma dersi alan öğrencilerde almayanlara göre daha yüksektir. Öte yandan bu farkın etki büyüklüğü küçüktür. Özel eğitim öz-yeterliği kimlik cinsiyeti ve sınıf düzeyine göre anlamlı fark göstermemektedir. Okul psikolojik danışmanı adayları özel eğitime ihtiyacı olan bir öğrenciyle karşılaşıldığında tanı ve değerlendirme için kurumlara başvuru, öğrenci için yapılacak eğitsel, kişisel/sosyal rehberlik, aileye ve öğretmenlere müşavirlik konularında bilgi sahibidir. Ancak, katılımcıların özel gereksinimli öğrencilere sunulacak mesleki rehberlik hizmetleri hakkında bilgi seviyelerinin arttırılmasına ve hak savunuculuğu ile ilgili sorumlulukları konusunda bilinçlendirilmeye ihtiyaçları olduğu söylenebilir. Nitel ve nicel bulgular birlikte düşünüldüğünde, katılımcıların bilgi eksikliklerinin olması özel eğitim öz-yeterliklerinin yüksek olmamasını açıklayabilir.

Çocuk Hakları Sözleşmesi "irk, dil, cinsiyet, etnik ya da toplumsal köken, mülkiyet, özür, doğum ve başka alanlarda farklılık gözetmeksizin bütün çocuklar için eşit ölçüde geçerlidir” (Birleşmiş Milletler Genel Kurulu, 1989). Dolayısıyla eğitimin temel bir insan hakkı ve daha adil bir toplum için elzem olduğu düşüncesinden hareketle, özel gereksinimli öğrencilerin eğitim ve rehberlik hizmetlerinden üst düzeyde faydalanması sağlanmalı ve bu konuda kilit konumdaki okul psikolojik danışmanı adaylarının yeterlilikleri arttırılmalıdır. Kaynaştırma dersi alan okul psikolojik danışmanı adaylarının özel eğitim öz-yeterlik algılarının daha yüksek olduğu düşünüldüğünde, lisans eğitiminde özel eğitimle ilgili ders almanın öz-yeterliğin artmasındaki önemi açıktır. Güncellenen ve 2018 yılından itibaren uygulamaya konan RPD Lisans programlarında (YÖK, 2018) özel eğitimle ilgili seçmeli derslerin olması umut verici olsa da bu araştırmaya katılan katılımcılar yeni programa tabi değildir ve özel eğitim konusunda aldıkları sınırlı seviyedeki eğitimle mezun olacaktır. Buradan hareketle, iki ders alarak mezun olan okul psikolojik danışmanlarının özel eğitim konusundaki öz-yeterliğinin ve yeterliliğinin desteklenmesine ihtiyaç duyulacağı düşünülmektedir.

Sonuç olarak bu çalışma nicel boyutuyla, okul psikolojik danışmanı adaylarının özel eğitim öz-yeterlik algılarına ilişkin bulgular sunarak önceki araştırmaları desteklemiştir. Aynı zamanda araştırmanın, okul psikolojik danışmanı adaylarının özel eğitim yeterliliklerini nitel yolla ölçerek, konu ile ilgili ilk bulguyu ortaya koyması bakımından alana özgün bir katkı sağladığı düşünülmektedir.

\section{Sınırlılıklar ve Öneriler}

$\mathrm{Bu}$ kısımda araştırmanın sınırlılıkları ve bu sınırlılıklara ilişkin araştırmacılara verilecek önerilere yer verilmiştir. Bu çalışmanın ilk sınırlılığı, katılımcıların özel eğitim dersi alıp almama ile özel eğitim öz-yeterlik puan ortalamaları karşılaştııılmak istense de katılımcıların yalnızca \%1.7'sinin $(n=4)$ özel eğitim dersi almadığını belirtmesi sebebiyle bu farkın test edilememesidir. Gelecek araştırmalarda özel eğitim dersi almamış okul psikolojik danışmanı adaylarına ulaşılarak özel eğitim öz-yeterlik düzeyleri karşılaştırılabilir. Standart hale getirilen YÖK programında (2018) özel eğitim dersinin yer almasından dolayı, gelecekte bir değişiklik yapılmadığı takdirde, Türkiye'de günümüz itibariyle eğitim alan okul psikolojik danışmanı adayları için söz edilen örnekleme ulaşılması mümkün görünmemektedir. Buradan hareketle bu karşılaştırmanın, bu dersin eğitim programında standart olarak yer almadığı ülkelerde ve üniversitelerde gerçekleştirilmesi önerilmektedir. 
Katılımcıların araştırmaya katılım gönüllülüklerinin azalmaması için araştırmanın nitel boyutunda kullanılan formun uygulama süresinin sınırlandırılması gerekmiştir. Bu gerekçeyle katılımcılara nitel formda yalnızca bir vaka sunulmuştur. Gelecek araştırmalarda farklı türde özel gereksinimi olan öğrencilere yönelik vaka örnekleri ile de çalışılabilir. Ayrıca araştırmacılar daha sınırlı sayıda katılımcıdan derinlemesine görüş alabilecekleri bireysel görüşme veya odak grup görüşmesi yöntemi kullanılan araştırmalar tasarlayabilirler. Aynı zamanda bu araştırmada yakınsak paralel karma desen seçildiğinden, nicel ve nitel formlar katılımcılara aynı anda sunulmuştur. Gelecek araştırmalarda sıralı karma desenler kullanılabilir. Böylece özel eğitim öz-yeterlik düzeyi düşük-orta-yüksek olarak belirlenen sınırlı sayıda katılımcıya ulaşılarak, özel eğitim öz-yeterlik düzeylerine göre karşılaştırılabilecek nitel veriler elde edilebilir.

\section{Yazarların Katkı Düzeyleri}

Öznur Bayar: Çalışma konusunu belirleme, verilerin analizi ve çalışmanın raporlanması. Türkan Doğan: Araştırma deseni, veri toplama ve çalışmanın raporlanması. 


\section{Kaynaklar}

Aksoy, V., \& Diken, İ. H. (2009a). Rehber Öğretmen Özel Eğitim Öz-Yeterlik Ölçeği: Geçerlik ve güvenirlik çalışması [School Counselors' Self-Efficacy Scale Regarding Special Education (SCSSSE): Validity and reliability results]. Ankara Üniversitesi Eğitim Bilimleri Fakültesi Özel Eğitim Dergisi, 10(1), 29-37. https://doi.org/10.1501/Ozlegt_0000000131

Aksoy, V., \& Diken, İ. H. (2009b). Rehber öğretmenlerin özel eğitimde psikolojik danışma ve rehberliğe ilişkin öz yeterlik algılarının incelenmesi [Examining school counselors' sense of self-efficacy regarding psychological counsultation and counseling in special education]. Elementary Education Online, 8(3), 709-719.

http://pauegitimdergi.pau.edu.tr/Makaleler/492403754_K.\%20Y\%c3\%bcksel,\%20\%c4\%b0.\%20H.\%20 Diken,\%20V.\%20Aksoy,\%20\%c3\%96.\%20Karaaslan.pdf

Ankara Üniversitesi Lisans Programı [Ankara University Undergraduate Program]. (2019). Rehberlik ve psikolojik danışmanlık lisans programı ders programı [Guidance and psychological counseling undergraduate program]. http://pdr.education.ankara.edu.tr/lisans-ders-programi/\#

Baltacı, A. (2017). Nitel veri analizinde Miles-Huberman modeli [Miles-Huberman model in qualitative data analysis]. Ahi Evran Üniversitesi Sosyal Bilimler Enstitüsü Dergisi, 3(1), 1-14. https://sbed.ahievran.edu.tr/makaleler/wzerrs tammetin.pdf

Bandura, A. (1982). Self-efficacy mechanism in human agency. American Psychologist, 37(2), 122-147. https://doi.org/10.1037/0003-066X.37.2.122

Birleşmiş Milletler Genel Kurulu [General Assembly of the United Nations]. (1989). Çocuk haklarina dair sözleşme [The convention on the rights of the child]. http://www.unicankara.org.tr/doc_pdf/metin132.pdf

Bodenhorn, N., \& Skaggs, G. (2005). Development of the school counselor self-efficacy scale. Measurement and $\begin{array}{lllll}\text { Evaluation in Counseling and Development, 38(1), 14-28. } & \text {. }\end{array}$ https://doi.org/10.1080/07481756.2005.11909766

Buyruk-Genç, A., \& Yüksel-Şahin, F. (2018). Psikolojik danışmanların kültüre duyarlı psikolojik danışma yeterliklerinin bazı değişkenlere göre incelenmesi [Investigation of multicultural counseling competencies according to certain variables]. Akademik Sosyal Araştırmalar Dergisi, 6(85), 593-618. http://dx.doi.org/10.16992/ASOS.14522

Cimsir, E. \& Hunt, B. (2018). Students with disabilities: Practical information for school counselors in Turkey. International Journal for the Advancement of Counselling, 40(2), 122-132. https://doi.org/10.1007/s10447-017-9315-x

Creswell, J. W. (2014). Research design: Qualitative, quantitative, and mixed methods approach (4th ed.). Sage Publications.

Creswell, J. W., Plano Clark, V. L., Gutmann, M. L., \& Hanson, W. E. (2003). Advanced mixed methods research designs. In A. Tashakkori \& C. Teddlie (Eds.), Handbook of mixed methods in social and behavioral research (pp. 209-240). Sage Publication.

Deniz, S. (2016). Rehber öğretmen adaylarının özel eğitime yönelik özyeterlik algılarının incelenmesi [The survey of pre-service counsellors' self efficacy perceptions towards special education]. Sosyal ve Beşeri Bilimler Araştırmaları Dergisi, 17(38), 154-175. https://dergipark.org.tr/tr/pub/sobbiad/issue/36454/413095

Dunn, N. A., \& Baker, S. B. (2002). Readiness to serve students with disabilities: Survey of elementary school

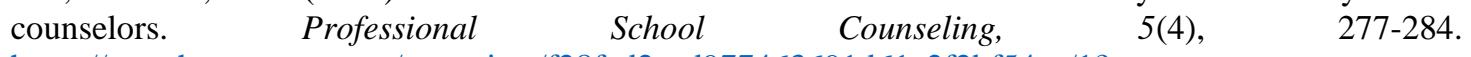
https://search.proquest.com/openview/f28fed2ccd977463691d61a2f2bf54aa/1?pqorigsite $=$ gscholar $\& \mathrm{cbl}=11185$

Fairchild, T. (1985). The school counselor's role as a team member: Participating in the development of IEPs. The School Counselor, 32(5), 364-370. https://www.jstor.org/stable/23901702 
Gazi Üniversitesi Bilgi Paketi [Gazi University Information Package]. (2020a). Rehberlik ve psikolojik danışmanlık programı özel eğitim ve kaynaştırma dersi [Guidance and psychological counseling undergraduate programme special education and inclusion course]. http://gbp.gazi.edu.tr/htmlProgramHakkinda.php?baslik=1\&dr=0\&lang $=0 \& a c=16 \& F K=05 \& B K=75 \& d$ ers_kodu=105032661http://gbp.gazi.edu.tr/htmlProgramHakkinda.php?baslik=1\&dr=0\&lang=0\&ac=16 $\& \mathrm{FK}=05 \& \mathrm{BK}=75 \&$ ders_kodu=105032661 http://gbp.gazi.edu.tr/htmlProgramHakkinda.php?baslik=1\& $\mathrm{dr}=0 \&$ lang $=0 \& \mathrm{ac}=16 \& \mathrm{FK}=05 \& \mathrm{BK}=75 \&$ ders_kodu $=105032661$

Gazi Üniversitesi Bilgi Paketi [Gazi University Information Package]. (2020b). Sosyal bilgiler ögrretmenliği programı özel eğitim ve kaynaştırma [Social sciences teaching programme special education and inclusion].

http://gbp.gazi.edu.tr $/ /$ htmlProgramHakkinda.php?baslik=1\&dr=0\&lang $=0 \& a c=16 \& F K=05 \& B K=15 \&$ ders kodu $=105032212$

Geltner, J. A., \& Leibforth, T. N. (2008). Advocacy in the IEP process: Strengths-based school counseling in action. Professional School Counseling, 12(2), 162-165. https://doi.org/10.1177/2156759X0801200206

Hacettepe Üniversitesi Ders Kataloğu [Hacettepe University Course Catalogue]. (2019). Rehberlik ve psikolojik danışmanlık programı [Guidance and psychological counseling undergraduate programme]. http://akts.hacettepe.edu.tr/ders_listesi.php?prg_ref=PRGRAM_0000000000000000000000161\&birim kod=446\&submenuheader $=2 \& \operatorname{prg}$ kod $=446$

Hacettepe Üniversitesi Ders Kataloğu [Hacettepe University Course Catalogue]. (2020a). EBB393 Özel Eğitim Dersi [EBB $393 \quad$ Special Education Course]. http://akts.hacettepe.edu.tr/ders_detay.php?ders_ref=DRSTNM_0000000000000000000006639\&ders_ kod=EBB393\&zs_link $=1 \&$ prg_kod=740\&submenuheader $=2$

Hacettepe Üniversitesi Ders Kataloğu [Hacettepe University Course Catalogue]. (2020b). ÇGL 282 Özel Eğitim $\begin{array}{llllll}\text { Dersi } & {[C \zeta G L} & 482 & \text { Special } & \text { Education }\end{array}$ http://akts.hacettepe.edu.tr/ders detay.php?ders ref=410c62643c5e0feb013c67acb84a4ce5\&ders kod= \%\%20C7GL282\&zs_link=1\&prg kod=446\&submenuheader $=2$

Heward, L. W. (2006). Exceptional children: An introduction to special education. Pearson Prentice Hall.

Kargın, T. (2007). Eğitsel değerlendirme ve bireyselleştirilmiş eğitim programı hazırlama süreci [The process for educational assessment and individualized education programme]. Ankara Üniversitesi Ĕgitim Bilimleri Fakültesi Özel Eğitim Dergisi, 8(1), 1-15. https://doi.org/10.1501/Ozlegt 0000000103

Kösterelioğlu, İ., \& Baytemir, K. (2016). Psikolojik danışma ve rehberlik öğrencilerinin özel eğitim dersi sürecindeki kazanımlarının belirlenmesi [Identification of psychological counseling and guidance students' gains during special education classes]. Marmara Üniversitesi Atatürk Eğitim Fakültesi Eğitim Bilimleri Dergisi, 44(44), 53-72. http://dspace.marmara.edu.tr/bitstream/handle/11424/6032/10.15285maruaebd.286485-283073.pdf? sequence=1\&isAllowed=y

Kumcağız, H., Demir, Y., \& Karadaş, C. (2017). Okul psikolojik danışmanlarında mesleki tükenmişliğin yordayıcısı olarak özel eğitime ilişkin öz-yeterlik algısı [Perceptions of self-efficacy regarding special education as a predictor of occupational burnout of school counselors]. İn̈nü Üniversitesi Eğitim Fakültesi Dergisi, 18(3), 312-324. https://doi.org/10.17679/inuefd.341495

Millı̂ Eğitim Bakanlığı [Ministry of National Education]. (2010). İlköğretim okullarındaki kaynaştırma uygulamalarının değerlendirilmesi [Evaluation of mainstreaming practices in primary schools]. Milli Eğitim Basımevi.

Millî Eğitim Bakanlığı [Ministry of National Education]. (2017). Rehberlik hizmetleri yönetmeliği [Guidance services legislation]. https://www.resmigazete.gov.tr/eskiler/2017/11/20171110-2.htm

Millı̂ Eğitim Bakanlığı [Ministry of National Education]. (2018). Özel eğitim hizmetleri yönetmeliği [Special education services legislation] https://orgm.meb.gov.tr/meb_iys_dosyalar/2018 07/09101900_ozel_egitim hizmetleri_yonetmeligi_07 072018.pdf 
Millî Eğitim Bakanlığı [Ministry of National Education]. (2019). Milli eğitim istatistikleri: Örgün eğitim 2018/'19 [National education statistics: Formal education 2018/'19]. Millî Eğitim Bakanlığı.

Millî Eğitim Bakanlığı [Ministry of National Education]. (2020a). Özel eğitim hizmetleri yönetmeliği [Special education services

https://orgm.meb.gov.tr/meb_iys_dosyalar/2020_06/24163215_ozel_eYitim_yonetmeliYi_son_hali.pdf legislation]

Millî Eğitim Bakanlığı [Ministry of National Education]. (2020b). Rehberlik ve psikolojik danışma hizmetleri yönetmeliği [Guidance and psychological counseling services legislation] https://orgm.meb.gov.tr/meb_iys_dosyalar/2017_11/10113305_yeni_rehbrlk_yon.pdf

Millî Eğitim Bakanlığı [Ministry of National Education]. (2020c). Rehberlik ve psikolojik danışma hizmetleri etik yönergesi [Guidance and psychological counseling services ethical legislation] https://orgm.meb.gov.tr/meb_ivs_dosyalar/2020_08/31230349_RPDH_Etik_Yonergesi_pdf

Myers, H. N. F. (2005). How elementary school counselors can meet the needs of students with disabilities. Professional School Counseling, 8(5), 442-450. https://www.jstor.org/stable/42732487

Niles, S. G., Goodman, J., \& Pope, M. (2018). Engelli bisikletçi vakası (A. G. İçin, Çev.). Ö. Ulaş \& T. Doğan (Eds.), Kariyer danışması vaka kitabı: Öğrenciler, uygulayıcılar ve psikolojik danışman eğitimcileri için bir kaynak içinde (ss. 396401). Nobel Akademi Yayıncılık. (Orijinal kitabın yayın tarihi 2011)

Owens, D., Thomas, D., \& Strong, L. A. (2011). School counselors assisting students with disabilities. Education, 132(2), 235 240. http://web.a.ebscohost.com/ehost/pdfviewer/pdfviewer?vid=0\&sid=6557cbde-d41a-4754-832577e 51881c5bb\%40sdc-v-sessmgr02

Sönmez, N., Koçyiğit, M., \& Gürel-Selimoğlu, Ö. (2020). Rehberlik ve psikolojik danışmanlık programı öğrencilerinin özel eğitimde öz-yeterlik algıları [School counselor candidates' perceptions of self-efficacy in special education]. Pamukkale Üniversitesi Eğitim Fakültesi Dergisi, 49, 484-505. https://doi.org/10.9779/pauefd.589837

Sucuoğlu, B. (1996). Kaynaştırma programlarında anne-baba katılımı [Parent involvement in inclusion programs]. Özel Eğitim Dergisi, $2(2)$,

$25-43$. https://dspace. ankara.edu.tr/xmlui/bitstream/handle/20.500.12575/47172/379.pdf? sequence=1\&isAllowed=y

Sucuoğlu, B. (2004). Türkiye'de kaynaştırma uygulamaları: Yayınlar/araştırmalar (1980-2005) [Mainstreaming practices in Turkey: Publications/researches]. Ankara Üniversitesi Ĕgitim Bilimleri Fakültesi Özel Ĕ̈itim Dergisi, 5(2), 15-23. https://dspace.ankara.edu.tr/xmlui/bitstream/handle/20.500.12575/47228/483.pdf?sequence=1\&isAllowed=y

Sütçü, Z. (2007). Yasal düzenlemeler açısından rehber öğretmenlerin/psikolojik danışmanların özel eğitimle ilgili görevlerini uygulamaya yönelik görüşlerinin değerlendirilmesi [Evaluation of the views of guidance counselor/psychological counselors regarding the implementation of special education duties in terms of legal regulations] (Tez Numaras1: 217359) [Yüksek lisans tezi, Selçuk Üniversitesi]. Yükseköğretim Kurulu Ulusal Tez Merkezi.

Turnbull, A., Turnbull, R., \& Wehmeyer, M. L. (2007). Exceptional lives: Special education in today's schools. Prentice Hall.

Yam, F. C., \& İlhan, T. (2016). Psikolojik danışma öz yeterliği: Kişilik özellikleri, kaygı düzeyleri ve geçmiş eğitim yaşantıları [Counseling self efficacy: Personality traits, anxiety levels and educational backgrounds]. Uluslararasi Sosyal Araştırmalar Dergisi, 9(42), 1304-1313. https://doi.org/10.17719/jisr.20164216242

Yeşilyaprak, B. (2016). 21. yüzyllda eğitimde rehberlik hizmetleri [Guidance services in education in the $21^{\text {st }}$ century] (26. bask1). Pegem Yayıncılık.

Yıldırım, A., \& Şimşek, H. (2003). Sosyal bilimlerde nitel araştırma yöntemleri [Qualitative research methods in the social sciences]. Seçkin yayıncıllk.

Yükseköğretim Kurulu [Council of Higher Education]. (2018). Rehberlik ve psikolojik danışmanlık lisans programı [Guidance and psychological counseling undergraduate programme]. https://www.yok.gov.tr/Documents/Kurumsal/egitim_ogretim_dairesi/Yeni-Ogretmen-Yetistirme-LisansProgramlari/Rehberlik_ve_Psikolojik_Danismanlik_Lisans_Programi.pdf

Yüksel, K., Diken, İ. H., Aksoy, V., \& Karaaslan, Ö. (2012). Rehber öğretmen adaylarının özel eğitimde psikolojik danışma ve rehberliğe ilişkin öz-yeterlik algıları [School counselor candidates' perception of self-efficacy regarding psychological counseling in special education]. Pamukkale Üniversitesi Eğitim Fakültesi Dergisi, 31(1), 137-148. https://app.trdizin.gov.tr/publication/paper/detail/TVRneU1qazVPUT09 


\section{Ankara University Faculty of Educational Sciences Journal of Special Education}

2021, 22(2), 369-394

\title{
School Counselor Candidates' Special Education Self-Efficacy Perceptions and Levels of Proficiency: A Mixed-Method Study
}

\author{
Öznur Bayar@1
}

\author{
Türkan Doğan 2
}

\begin{abstract}
Introduction: School counselors have critical role in special education services. However, limited number of studies have examined school counselor candidates' self-efficacy and proficiency.

Method: Convergent parallel mixed design was used. The aim was to examine school counselor candidates' selfefficacy perceptions and their proficiency levels regarding special education. Quantitative method was used to measure self-efficacy ("School Counselors' Self-Efficacy Scale regarding Special Education”). Qualitative method ("Case Presentation and Case Questionnaire") was used to measure the proficiency. The participants were Guidance and Psychological Counseling students from junior senior class $(n=233)$.

Findings: Findings indicated special education self-efficacy of the participants was at a medium level. No significant difference was found between the special education self-efficacy according to gender and class. Special education self-efficacy was higher among those who took inclusion course. Participants had information regarding the need to refer the child to diagnosis- evaluation, educational and personal/social guidance for student, and consultancy for family/teachers. However, participants presented less information on vocational guidance and advocacy.

Discussion: Medium level of special education self-efficacy is consisted with previous studies and it may be about the limited level of education regarding special education. It was observed that school counselor candidates need to increase their knowledge about vocational guidance services. Advocacy was also less evident in participants' responses which is an important part of school counseling and therefore the information about advocacy needs to be increased.

Keywords: School counselor candidates, special education, school counseling and guidance in special education, school counselor candidate's special education self-efficacy, special education proficiency, case presenting, mixed method.
\end{abstract}

To cite: Bayar, Ö., \& Doğan, T. (2021). School counselor candidates' special education self-efficacy perceptions and levels of proficiency: A mixed-method study. Ankara University Faculty of Educational Sciences Journal of Special Education,22(2), 369-394. https://doi.org/10.21565/ozelegitimdergisi.695682

\footnotetext{
${ }^{1}$ Corresponding author: Res. Asisst., Hacettepe University, E-mail: oznur.bayar@ hacettepe.edu.tr, https://orcid.org/00000002-9385-8641

${ }^{2}$ Prof. Dr., Hacettepe University, E-mail: dogant@ hacettepe.edu.tr, https://orcid.org/0000-0002-5976-7666
} 


\section{Introduction}

All the children including those with special education needs have the right to education. In Turkey, special education aims the inclusion of all the children. Various institutions and organizations should work in cooperation to achieve this aim. School counselors have a critical role in this process. Classroom teachers and school counselors should work together in the process of recognizing students in need of special education, and filling children's needs in the classroom (Kargin, 2007). School counselors also take an active role in guidance services for students who are in need of special education, their families and their teachers. These services can be considered as a consultancy (Yeşilyaprak, 2016). Another responsibility of the school counselor is the advocacy. Although legal regulations have been made for students with special needs, the need for advocacy may arise in order to protect the rights of students in need of special education. The school counselor may become the authority to inform students' families, teachers and other staff at the school (Cimsir \& Hunt, 2018).

Self-efficacy perceptions of counselors regarding special needs seem to be related to their performance about these services (Aksoy \& Diken, 2009a). The perception of self-efficacy levels of school counselors who are experienced about special education is reported to have higher special education self-efficacy (Aksoy \& Diken, 2009b). Therefore, knowledge and experience may affect self-efficacy perception. Although the role of school counselors in special education is valuable, the education level regarding special education before or after graduation is low (Dunn \& Baker, 2002). As a result of that, the level of the special education self-efficacy may be limited among those who do not take enough number of courses regarding special education. According to Cimsir and Hunt (2018), legislation about guidance services does not have a clear regulation about the role of school counselors regarding special education in Turkey. Thus, the aim of this research was to examine the school counselor candidates' self-efficacy perceptions and proficiency levels regarding special education.

\section{Method}

A convergent parallel mixed design was used in the study. Mixed methods can be preferred when indepth knowledge is needed in educational and social sciences (Creswell et al., 2003). The quantitative method was used to measure the special education self-efficacy perception of the participants. The qualitative method was used to measure the proficiency of the participants who were Guidance and Psychological Counseling students from junior and senior class $(n=233)$. Total of 186 participants $(79.8 \%)$ were women and $47(20.2 \%)$ were men. Total of 229 participants $(98.3 \%)$ stated that they took "Special education course"; $4(1.7 \%)$ stated that they did not take this course and 74 of the participants (31.8\%) took "Inclusion course"; 159 (68.2\%) did not take this course.

School Counselors' Self-Efficacy Scale regarding Special Education (SCESSSE) was used as an instrument (Aksoy \& Diken, 2009a). t is a 5-point scale with 40 items to test self-efficacy levels of school counselors. It can also be used with school counselor candidates (Yüksel et al., 2012). Also, "Case Presentation and Case Questionnaire" were used to examine the proficiency of participants about special education. Two experts in the fields of special education and psychological counseling and guidance examined this questionnaire and found the form appropriate. Minor changes were made in accordance with their suggestions. Only one case was presented in order to ensure voluntary participation. In the case presentation, a classroom teacher referred a student to a school counseling service and the student was having difficulties with fluency and expression while speaking and having anxiety about it. She was a $4^{\text {th }}$ grade student in elementary school and had difficulty in English and Turkish lessons and when she communicated with her friends. After presenting the case, the following questions were asked to the participants: (1) To which institutions would you refer this student in order to identify whether your student had language or speech impairment? How would you follow the referral process? (2) What kind of counseling service would you offer to this student? What kind of services would you offer within the scope of educational, vocational and personal/social guidance? (3) What kind of support would you offer to this student's family? What kind of counseling services would you provide? (4) What kind of support would you offer to this student's classroom teacher? What kind of counseling services would you provide? If they had no idea about the answers, they were asked to select the option entitled "I have no idea" for each question. The personal information form was also used to collect demographic information about participants.

Quantitative data about the perception of self-efficacy was tested through descriptive statistics. Independent samples t-test was used to see if there was a significant difference between special education selfefficacy according to gender, class level and whether they took an inclusion course or not. 
Qualitative data were analyzed through descriptive analysis (Yıldırım \& Şimşek, 2003). The data were first coded into the Microsoft Office's Word program. Each answer of the participants was examined thoroughly in order to be familiar with the data. Descriptive codes were given regarding the responses, which served to cluster the data. The first level codes were brought together as meaningful structures and themes emerged. In the last step, the data were interpreted and presented in the findings. Creswell's (2014) suggestions were followed throughout the qualitative data analysis process. The excerpts that belonged to the participants were presented in the following sections.

\section{Results}

\section{Quantitative Findings}

The special education self-efficacy perception levels of the participants were examined in this section. Descriptive statistics related to the special education self-efficacy scores of the participants were presented in Table 1.

Table 1

Descriptive Statistics of the Participants' Special Education Self-Efficacy Scores

\begin{tabular}{ccccccc}
\hline Scale & Score range & Level & $f$ & $\%$ & $\bar{X}$ & $s d$ \\
\hline \multirow{3}{*}{ SCESSSE $^{\mathrm{a}}$} & $64-101$ & Lower & 23 & 9.9 & & \\
& $102-162$ & Middle & 196 & 84.1 & 132.13 & 22.70 \\
& $163-200$ & Upper & 14 & 6.0 & & \\
\hline
\end{tabular}

aschool counselors' self-efficacy scale regarding special education.

The scores ranged between 64 and 200 for SCESSSE. The mean score was found to be $132.13(s d=$ 22.70). Lower (64-101), middle (102-162) and upper (163-200) groups were identified with z scores which were calculated by taking the average scores of the participants into account. The average score of the participants was found to be at a medium level.

Secondly, the study examined whether there were differences between the special education self-efficacy scores and some of the variables. The results of independent groups t-test regarding whether there was a difference according to the participants' special education self-efficacy levels, class levels, and whether they took inclusion course or not as shown in Table 2.

Table 2

Independent Groups T-Test Results Regarding Gender, Class Levels, and Whether They Took Inclusion Course

\begin{tabular}{cllcccccc}
\hline Scale & Variable & \multicolumn{1}{c}{ Groups } & $n$ & $\bar{X}$ & $s d$ & $d f$ & $t$ & $p$ \\
\hline \multirow{2}{*}{ Gender } & Women & 186 & 131.77 & 22.63 & \multirow{2}{*}{231} & -.481 & .631 \\
& & Men & 47 & 133.56 & 23.18 & & & \\
\multirow{2}{*}{ SCESSSE $^{\mathrm{a}}$} & & & & & & \\
& \multirow{2}{*}{ Inclusion course } & Took a course & 74 & 138.98 & 23.60 & & & \\
& & Did not take a course & 159 & 128.94 & 21.61 & 231 & 3.207 & $.002^{*}$ \\
& \multirow{2}{*}{ Class level } & Junior & 118 & 129.44 & 23.09 & & & \\
& & Senior & 112 & 135.15 & 21.96 & 228 & -1.919 & .056 \\
\hline
\end{tabular}

a'School counselors' self-efficacy scale regarding special education.

${ }^{*} p<.05$.

The differences between the mean scores of special education self-efficacy of women and men were not significant $(t(231)=-.481, p>.05)$. On the other hand, the differences between the special education self-efficacy scores of the participants who took the inclusion course and who did not take the inclusion course were significant $(t(231)=3.207, p<.05)$. The effect size of this difference was small (Cohen's $d=.04)$. The special education selfefficacy levels between junior and senior students were not significant $(t(228)=-1.919, p>.05)$.

\section{Qualitative Findings}

In this section, the findings related to the qualitative part were presented. Total of 39 participants (16.7\%) did not answer any questions in this section. The participants who answered at least one question were included in qualitative analysis $(79.4 \%, n=185)$. The number of the expressions, not the number of the participants, was determined and expressed as frequency $(f)$. Each participant was given a code. The codes were assigned with the number of themes and letter codes of the category/sub-category (For example, 1-a or 2-a-i). The answers given to 
each question were presented in Table 3, Table 4, Table 5 and Table 6 which included themes, categories and subcategories, frequency of responses $(f)$.

Table 3

Findings About the Referral Steps to Institutions for Diagnosis and Evaluation

\begin{tabular}{|c|c|c|}
\hline Themes & Categories and sub-categories & $f$ \\
\hline \multirow{6}{*}{ 1. Referral institution/specialist } & (a) $\mathrm{GaRC}^{\mathrm{a}}$ & 88 \\
\hline & (b) $\mathrm{SLT}^{\mathrm{b}}$ or audiologist & 23 \\
\hline & (c) Doctor & 11 \\
\hline & (d) Special education center & 10 \\
\hline & (e) Psychiatrist & 5 \\
\hline & Total & 137 \\
\hline \multirow{13}{*}{ 2. Steps of the referral process } & (a) Direct referral & 35 \\
\hline & (b) Gathering information about the student (from) and then refering: & \\
\hline & i. Teachers & 10 \\
\hline & ii. Special educationalists & 7 \\
\hline & iii. Family & 6 \\
\hline & iv. Through observation & 5 \\
\hline & v. From written sources & 2 \\
\hline & Total & 30 \\
\hline & (c) Providing information about the student and then referring (to): & \\
\hline & i. Family & 14 \\
\hline & ii. School administration & 10 \\
\hline & iii. Teachers & 1 \\
\hline & Total & 25 \\
\hline 3. No idea & & 20 \\
\hline \multirow{3}{*}{ 4. Other } & (a) Assessment-diagnosis & 2 \\
\hline & (b) Other statements that reflect the lack of information & 10 \\
\hline & 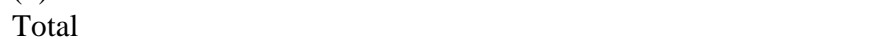 & 12 \\
\hline
\end{tabular}

${ }^{a}$ Guidance and research centers. ${ }^{b}$ Speech and language therapist.

The first finding was about "the referral institution/specialist, steps of the referral process for diagnosis and evaluation". 165 of the participants (89.2\%) answered this question. The responses were presented in Table 3. Some of the answers to this question were as follows:

"K9: I would refer the student to GaRC (1-a), K39: I refer student to the SLT (1-b), K19: I would refer to the doctor to see if she had a physical impairment (1-c), K23: I would collect information by talking to the teachers and, if this raised my doubts, I would refer her to GaRC (2-b-i), K44: I would inform the family and the principal before I refer the student to the GaRC (2-c-i and 2cb-ii), K114: I would refer her to the dyslexia association (4-b)."

Table 4

Findings of Educational, Vocational, Personal/Social Guidance Services for the Student

\begin{tabular}{|c|c|c|}
\hline Themes & Categories and sub-categories & $f$ \\
\hline \multirow{5}{*}{ 1. Educational guidance } & (a) Planning educational activities & 24 \\
\hline & (b) Adaptation to the lessons & 23 \\
\hline & (c) Cooperation with special education institutions & 15 \\
\hline & (d) IEPa services & 12 \\
\hline & (e) Reading activities & 11 \\
\hline \multirow{4}{*}{ 2. Vocational guidance } & Total & 85 \\
\hline & (a) Career counseling & 9 \\
\hline & (b) Individual self-knowledge services & 5 \\
\hline & Total & 14 \\
\hline
\end{tabular}


Table 4 (continue)

\begin{tabular}{llc}
\hline Themes & \multicolumn{1}{c}{ Categories and sub-categories } & f \\
\hline & (a) Individual services & 67 \\
& i. Psychological counseling/individual interview & 2 \\
& ii. Breathing/speaking exercise & 16 \\
3. Personal/social guidance & (b) Group work & 23 \\
& i. Group guidance/group counseling & 10 \\
& ii. Peer relations/social skills development studies & 2 \\
& iii. In-class activities for student's social acceptance & 120 \\
& iv. Drama activities & 6 \\
T. Tdal & & 12 \\
5. No idea & & 17 \\
& & 7 \\
6. Other & (a) Educational, personal/social and/or vocational guidance & 2 \\
& (b) Referring (SLT ${ }^{\mathrm{b}}$, audiologist etc.) & 18 \\
& (c) Adaptations in guidance activities & 44 \\
\hline
\end{tabular}

${ }^{\mathrm{a}}$ Individualized education plan. ${ }^{\mathrm{b}}$ Speech and language therapist.

The second finding was about educational, vocational, personal/social guidance services for the student. The responses were presented in Table 4. Some of the answers to this question were in the following:

"K32: In educational terms, I would start the process for IEP (1-e), K20: I would inform her friends and teachers and invite experts to my school to raise awareness (4), K4: I would send her to speech and language therapist. Thus, educational, professional and social problems would not occur, K18: I would prepare IEP (6-d)."

Table 5

Findings of Guidance Services for the Family of the Student with Special Needs

\begin{tabular}{llc}
\hline \multicolumn{1}{c}{ Themes } & \multicolumn{1}{c}{ Categories } & $f$ \\
\hline \multirow{3}{*}{ 1. Informing the family } & (a) Student's condition/SLD & 73 \\
& (b) Supporting the development at home & 52 \\
& (c) How to treat their children & 28 \\
& Total & 153 \\
2. Providing parent involvement & (a) Planning family interviews & 31 \\
& (b) Providing support from other parents & 3 \\
& (c) Planning home visits & 3 \\
3. Referring the family to special education & Total & 21 \\
institutions & & 17 \\
4. Advocating & & 11 \\
5. No idea & & 4 \\
6. Other & (a) Consultation & 16 \\
& (b) Statements that reflect the lack of information & 20 \\
\hline
\end{tabular}

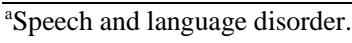

(b) Statements that reflect the lack of information

The third finding included the guidance services for the families of students with special needs. The responses were presented in Table 5. Some of them were shown in the following:

"K83: I would describe what they could do to support school education at home (1-b), K34: I would provide information on how to treat her so that her psychological and physiological health is good (1-c), K101: I would keep in touch with the family. I would regularly arrange family-school meetings (2-a), K131: I would explain their and their children's legal rights (4), K94: I would say (to the family), if your child has such a condition, it can be improved with simple interventions (6-b)." 
Table 6

Findings of Guidance Services for Students with Special Needs

\begin{tabular}{llc}
\hline \multicolumn{1}{c}{ Themes } & \multicolumn{1}{c}{ Categories } & $f$ \\
\hline & (a) Student's condition/SLD & 56 \\
& (b) Student's in-class integration & 43 \\
1. Informing the teacher & (c) How to treat the student & 40 \\
& (d) The educational development of the student & 34 \\
& (e) Related to SLT & 15 \\
& (f) Student's assessment & 3 \\
2. Cooperation with the teacher & Total & 191 \\
3. Advocating & & 19 \\
4. No idea & & 13 \\
5. Other & (a) Statements that reflect the lack of information & 19 \\
\hline${ }^{a}$ Speech & & 11 \\
\hline
\end{tabular}

${ }^{a}$ Speech and language disorder. ${ }^{b}$ Speech and language therapist.

Fourth finding was about the services for the teachers of the student with special needs. The responses were presented in Table 6 . Some of the excerpts in this category were in the following:

"K12: I would describe how to treat a student with special needs. I would tell them not to ignore her and be patient (1-c), K30: I would always follow Selin's development in cooperation with her teacher (2), K102: I would inform her teachers and all school staff (3), K89: I would like the teacher to act in accordance with the IEP I prepared for them (5-a), K68: I would state that they should be preparing the IEP for the student, necessary arrangements has to be made and this is a legal obligation (3)."

\section{Discussion and Conclusion}

The participants' perceptions of special education self-efficacy were at the medium level. This finding was supported by previous studies that included school counselors (Deniz, 2016) and school counselor candidates (Sönmez et al., 2020). One of the reasons for not having a high level of special education self-efficacy may be about the limited level of education about special education. There were at most two courses in the Guidance and Psychological Counseling Programs that continued until 2018 in undergraduate education. As the level of experience related to special education increases, the self-efficacy perception also increases (Aksoy \& Diken, $2009 \mathrm{~b}$ ). Therefore, not having high level of special education self-efficacy was expected for participants.

No significant difference was found between the special education self-efficacy scores according to the gender. This supports the findings of two studies (Deniz, 2016; Sönmez et al., 2020), but contradicts with the finding of one study (Yüksel et al., 2012). However, the effect size of the difference in the last study was observed as small (Yüksel et al., 2012). Therefore, gender may not have a great effect on self-efficacy regarding special education.

No significant difference was found between the special education self-efficacy scores between junior and senior students. Almost all of the participants took and completed special education course $(98.3 \%, n=229)$ and some of them took inclusion course $(31.8 \%, n=74)$. This could explain how their scores did not differ from each other.

Some of the participants stated that $(16.7 \%, n=39)$ they have no idea about the questions related to the case that was presented in the study. Thus, their qualitative data was excluded. The first finding included "the referral institution and steps of the referral process for diagnosis and evaluation". Most of the answers contained referral statements to GaRC $(f=88)$; SLT's or audiologists $(f=23)$ or doctors $(f=11)$. The responses were examined according to the legal process in terms of the duties of the school counselors in Turkey (See Ministry of National Education [MoNE], 2020a).

Regarding the steps of the referral process for diagnosis and assessment, most of the expressions involved direct referral $(f=35)$. Previous studies revealed that school counselors preferred to refer the child to GaRC directly without making any arrangement about the student due to a lack of information (Sütçü, 2007). Some statements about the referral steps were related to gathering information from various sources about the student (from his family, observation, etc.) or $(f=30)$ informing various stakeholders about the student (including family, teachers, 
etc.). This process was in line with the Special Education Services Regulation (see MoNE, 2020a). Therefore, informing the family and the school administration first, and then to starting the referral processes were considered as appropriate steps.

The most frequent views about educational guidance for the student were about planning educational activities $(f=24)$, adaptation to the lessons $(f=23)$, cooperation with special education institutions $(f=12)$, IEP services $(f=12)$ and reading activities $(f=11)$. Most of them stressed a cooperation with the teacher and GaRC. On the other hand, some expressions reflected the lack of information about the responsibilities of school counselors. For example, some of the participants stated: "I would prepare IEP". However, school counselors are exptected to attend to the IEP development team to provide guidance services about the student (MoNE, 2018).

The most frequent opinions within the scope of vocational guidance included career counseling $(f=9)$ and selfknowledge activities $(f=5)$. Since vocational guidance services are aimed at all students (Yeşilyaprak, 2016), these services should include students in need of special education. Some of the responses were against social justice as they included: "I let students understand the professions they can and cannot do". However, both the psychological and career counseling services should be multicultural (Buyruk-Genç \& Yüksel-Şahin, 2018). Thus, the goal of multicultural career counseling does not include to determine what students can and cannot do. Counselors should realize the educational, occupational, personal/social needs of children and offer them a proffesional guidance for meeting their all needs (Myers, 2005).

Regarding the findings of counseling services to the family, the most frequent opinions included informing the family $(f=153)$, parent involvement $(f=37)$ and referring family to special education institutions $(f=21)$. Providing family participation in the special education or inclusion process affects the success and outcomes of the inclusion programs (Sucuoğlu, 1996). Some of the responses about informing the family regarding the student's condition can be considered as the advocacy as these answers emphasized the legal rights of the children and the family. However, the statements about advocacy were less evident. Therefore school counselor candidates should be informed about advocacy and social justice.

As for the findings about the counseling services for the teachers, the most frequent opinions were informing the teacher $(f=191)$ and cooperating with the teacher $(f=19)$. According to literature, school counselors choose to conduct in-class entegration activities with the teacher and they follow the student in collaboration (Sütçü, 2007). The statements of the participants directly about the rights of the students were evaluated within the scope of advocacy in this theme $(f=13)$. Although there were statements about social justice and advocacy for children with special needs, they were less evident.

As a result, the special education self-efficacy of the school counselor candidates was found to be medium. Special education self-efficacy was higher among students who took an inclusion course. Whereas, it did not differ according to gender and class level. The effect size of the difference between two groups were small. The school counselor candidates had knowledge about referring to institutions for diagnosis and assessment, educational, personal/social guidance for the student, and consultancy for parents and teachers. It can be said that the school counselor candidates need to increase their knowledge about vocational counseling and guidance services. They also need to be gain an understanding about advocacy. Considering qualitative and quantitative findings together, the lack of proficiency of the participants may explain the lack of special education self-efficacy.

\section{Limitations and Suggestions}

The limitation of this study was the inability to compare those who took the "Special Education" course and those who did not. Almost all of the participants stated that they took this class in previous years $(98.3 \%, n=229)$. In future studies, special education self-efficacy levels can be compared by reaching the school counselor candidates who have not taken the special education course.

In order to not to influence voluntary participation, the time allocated to the data collection had to be limited. For this reason, only one case with a speech and language disorder was presented to the participants. Future studies can focuss on other special education needs. Since the convergent parallel mixed design was chosen in this research, qualitative and quantitative forms were presented to the participants at the same time. The sequential mixed designs can be utilized in future studies.

\section{Author's Contributions:}

Öznur Bayar: Subject of the manuscript, data analysis and reporting of the study. Türkan Doğan: Research design, data collection and reporting of the study. 